\title{
The Motherhood Wage Penalty in Times of Transition ${ }^{1}$
}

\section{Olena Y. Nizalova ${ }^{\dagger}$, Tamara Sliusarenko*, and Solomiya Shpak}

\author{
$\dagger$ PSSRU/CHSS, University of Kent/IZA \\ * TDC Group \\ + George Mason University \\ Abstract
}

Depopulation trend in Ukraine caused to a large extent by the lowest low fertility rates raises serious concerns about long-term economic growth and the country's future in general. In this paper we investigate the existence and the extent of the motherhood wage penalty as a potential impediment to having (more) children in a unique institutional environment. This environment is characterized by: de jure family supportive labor laws but de facto no legal enforcement of these laws; publicly subsidized childcare; and low cultural support for maternal employment, combined with extensive involvement of grand-parents. Relying on the data from the Ukrainian Longitudinal Monitoring Survey over the period from 1997 to 2007, we find that the overall motherhood wage penalty in Ukraine is much lower than in countries with similar de jure family policies and cultural norms. It constitutes approximately $19 \%$, controlling for individual unobserved heterogeneity, a number of human capital characteristics, actual time in the labor force, and selection into employment. We also find that the motherhood wage penalty differs by education, age at birth of first child, and marital status.

\footnotetext{
${ }^{1}$ The authors are grateful to Nataliia Shapoval for her excellent research assistance, Ina Ganguli for the constructive review and valuable suggestions, lan Svejnar and other participants of the International Symposium "Ukraine: Escape from Post-Soviet Legacy" for their useful comments and suggestions, and Jane Dennett for editing advice.
} 


\section{Introduction}

Since its independence, Ukraine has been experiencing decades-long demographic crisis due to high out- and low in-migration, a severe population health crisis and high mortality (especially among prime-aged males), as well as the "lowest low" fertility rates (Perelli-Harris 2005). This has led to a population decline from more than 52 million people to 42.5 million people in 2015 , which shows no signs of reversal in the near future. Moreover, this demographic crisis is associated with considerable changes in the population age structure, with the share of population aged $65+$ projected to increase to $26.3 \%$ by the year 2050 (Safarova, Scherbov and Pirozhkov 2008). This raises concerns about further declines in the rate of economic growth (Bloom, Canning, and Fink 2010, Lisenkova, McQuaid, and Wright 2010), as well as sustainability of the pension system and, therefore, calls for the prioritization of the policies affecting demographic trends.

In spite of the existence of indirect policies, such as maternal/parental leave and antidiscrimination labor market laws, currently only the baby bonus (a government payment to parents of a newborn baby or adopted child to assist with the costs of childrearing) is discussed in Ukrainian policy circles as a measure to address the issue of low fertility. Over the course of 1990s this bonus had been set at an extremely low level but had been increased several times over the course of the 2000s (See Appendix Table A1). Although no rigorous evaluation of this pro-natalist policy has been undertaken, limited publications in Ukrainian sources (including government reports) show no plausible evidence that the existing baby bonus results in a noticeable impact on the overall fertility, mostly shifting of the timing of births by those who would have had the same number of children anyway. There are also some concerns about sizeable increases in fertility among poor and marginalized population groups, where sometimes the baby bonus becomes the only source of income. ${ }^{2}$ Potentially, this indicates that there is a factor (e.g. a motherhood wage penalty) not taken into account by policy makers, which may be misleading their choices of policy measures. One obvious candidate is the wage gap between mothers and non-mothers (the motherhood wage penalty), which would be consistent with the disproportionate effect of the baby bonus across the income distribution.

The motherhood wage penalty is a well-documented phenomenon in economics literature. Maternity can have a negative impact on women's opportunities in the labor

\footnotetext{
${ }^{2}$ http://old.niss.gov.ua/Monitor/desember08/25.htm, http://www.dsnews.ua/society/shcho-vplivae-na-rivennarodzhuvanosti-09032015103800, http://www.niss.gov.ua/articles/940/.
} 
market, not only through the decrease of hours devoted to work, but also through career interruptions, loss of human capital while child caring, smaller mobility compared to women without children, lower productivity on the job during the period when children are small, as well as due to statistical discrimination. An interesting feature of the most recent literature in this area is that the motherhood wage penalty still exists, albeit becoming somewhat smaller, after controlling for most of the above-mentioned human capital related explanations, and selection into employment. The magnitude of the remaining motherhood wage penalty varies significantly from virtually zero in Finland, Sweden, Belgium, Israel, to small (5-10\%) in France, Canada, UK, Poland, Slovakia and Czech R., to moderate (10-15\%) in US, Russia and Hungary, and large (20-33\%) in most of continental Europe and Ireland (Budig, Misra, and Boeckmann 2012). Some authors have tried to explore this cross-country variation with respect to the institutional settings and cultural norms, with most focus on family policies.

A broad range of family policies has been advocated and introduced around the world over the past decades, mainly in industrialized countries but also in the post-socialist states and some developing countries. The aim of these policies has been to ease the conflict between women's career choices and fertility by addressing those market processes which are putting women at a disadvantage in the labor market. The most widespread policy in this spectrum is the maternal/parental leave system promoted by the International Labour Office through its three Maternity Protection Conventions (No. 3 in 1919, No. 103 in 1952, No. 183 in 2000). ${ }^{3}$ So far, 66 ILO member states have ratified at least one of those three Conventions, and 43 have ratified the ILO Workers with Family Responsibilities Convention (No. 156 in 1981) which marked the recognition that "a change in the traditional role of men as well as the role of women in society and in the family is needed to achieve full equality between men and women" (ILO 2014). These maternal/parental leave policies are usually stipulated as mandates which establish job retention rights over a specified period of time following childbirth. Although such mandates are cheap for governments to introduce and can be beneficial in terms of limiting the wage effects of work interruptions via retaining the workers' firm-specific human capital, they are imposing considerable non-wage costs on employers which in the equilibrium are transmitted into lower wages for women (Ruhm 1998).

\footnotetext{
${ }^{3}$ http://www.ilo.org/global/standards/subjects-covered-by-international-labour-standards/maternity-protection/lang-en/index.htm
} 
Another complementary policy is provision of subsidized or publicly provided childcare, which increases women's incentives to paid work via two channels: "directly raising earnings net of childcare costs and lowering the opportunity cost of employment through access to quality childcare" (Gangl and Ziefle 2009). By design, the cost of this type of family policy is borne by taxpayers and therefore is not passed directly or indirectly onto working mothers or working women in general. The degree of generosity and the extent of coverage of these policies have been considered in the most recent literature as potential explanations for the cross-country differences in the motherhood wage penalty. For example, the highest wage penalty for motherhood is found in Germany, where the maternity leave policy is very generous but pre-kindergarten childcare is rather weak (Gangl and Ziefle 2009).

Another strand of literature relates the motherhood wage penalty and family policies through the prism of cultural norms. It reaches the conclusion that both parental leave and public childcare are associated with higher earnings for mothers when cultural support for maternal employment is high, while putting upward pressure on the motherhood wage penalty where cultural attitudes support the male breadwinner/female caregiver model (Budig, Misra, and Boeckmann 2012).

Documenting the existence and extent of the motherhood wage penalty in Ukraine is very timely and policy relevant, given the serious concerns about the demographic crisis. Moreover, in light of the above-mentioned literature relating the size of the motherhood wage penalty to the interaction between the institutional settings and cultural norms, Ukraine represents an academically interesting context to study the phenomenon. First of all, it has relatively generous maternity leave policy: $100 \%$ paid maternity leave of 18 weeks, and the possibility to take unpaid leave of up to three years and, in case of child sickness, up to six years, with a mandated guarantee of return to the same workplace. In addition, such a leave, with a guaranteed return to workplace, can be taken by any other close relative of the child (e.g. father, grandmother, grandfather). Second, Ukraine has inherited an extensive network of public childcare facilities which can accommodate children from very a early age as women in the Soviet Union did not have extended maternity leave up to the mid-1980s. These facilities have always been heavily subsidized through local and state funding. Therefore, following the literature we should expect to either find a negligible or no motherhood wage penalty, as in the Scandinavian countries with high degree of cultural support for maternal employment, or a high motherhood wage penalty as, for example, in Germany, where the degree of such support is low. However, compared to Germany, Ukraine has two important 
differences: the quality of the legal environment with respect to the enforcement of familyfriendly and anti-discrimination labor market policies; and cultural norms supporting significant involvement of grandparents in childcare, combined with the relatively early retirement age. The former undermines workers' ability to protect their rights in courts, which would imply no economic costs of maternity leave mandates for employers. The latter lowers the opportunity cost of employment by increasing availability of alternative high-quality child care. Both work towards lowering the motherhood wage penalty. In this paper we extend the previous literature by investigating the motherhood wage penalty in this unique institutional environment and form policy recommendations.

We explore the motherhood wage penalty after controlling for various human capital characteristics and selection into the labor market to arrive at the estimates of the motherhood wage penalty comparable to those from other countries/studies. Constructing the panel data from the Ukrainian Longitudinal Monitoring Survey (ULMS) ${ }^{4}$ for the period 1997-2007 and estimating the fixed-effect model, we find the overall motherhood wage penalty of approximately 19\%. Females with only one child earn $17 \%$ less than females without children, and females with two or more children earn 29\% less per hour. Our analysis reveals heterogeneity in the estimates across educational groups and depending on the age at first birth. Women with higher education suffer the lowest motherhood wage penalty compared to those with lower levels of education (11\% vs. $18 \%$ per child). There is no evidence of benefit in postponing the age at first birth. On the contrary, delaying first birth until the mother is aged 30 and above is associated with the highest motherhood wage penalty, but only among those with the lowest levels of education. In addition, the motherhood wage penalty is highest for those who are not married.

The magnitude of the overall motherhood wage penalty falls short of the estimate of $33 \%$ for Germany, which also has generous family policies and low cultural support for maternal employment. In fact, it lies within the range of the moderate motherhood wage penalty between 16\% for Spain and 21\% for Ireland (Budig, Misra, and Boeckmann 2012), which exhibit high cultural support for maternal employment. This suggests that poor legal environment and high cultural support of grand-parenting (combined with low retirement age) keep the motherhood wage penalty at bay.

\footnotetext{
$4 \underline{\text { H. Lehmann, A. Muravyev, and K.F. Zimmermann "The Ukrainian Longitudinal Monitoring Survey: Towards a Better }}$ Understanding of Labor Markets in Transition", in IZA Journal of Labor and Development, 2012, 1, Article 9.
} 
However, there is an indication that this may change in the near future. After the Revolution of Dignity, ${ }^{5}$ the country is finally on its way to establish credible institutions first and foremost this relates to the legal system working towards enforcement of existing legislation. Therefore, we shall expect an increase in the motherhood wage penalty due to this factor. This pressure will be reinforced by the Pensions reform through a gradual increase in the retirement age, which would limit availability of grandparents for care provision. Hence, countermeasures should be devised in time to balance off such unintended consequences of these much-needed reforms targeting the dire demographic situation. We recommend two options: investment in quality and increased availability of public childcare centers and/or creation of favorable conditions for private initiatives in this sector, as well as information campaigns which promote positive attitudes towards maternal employment.

The remainder of the paper is organized as follows. Section 2 provides an overview of the previous literature concerning the motherhood wage penalty. Section 3 describes family policies, cultural norms and de facto employment practices in Ukraine. The underlying methodology is presented in Section 4 followed by a description of the data in Section 5 . Estimation results as well as econometric issues pertinent to the current analysis are discussed in Section 6, while Section 7 offers conclusions and policy recommendations.

\section{Literature Review}

Economists relate labor market consequences of motherhood to re-allocation of time, lower investment in human capital, deterioration of human capital due to career interruptions, changes in productivity and work effort, changes in preferences for specific job amenities, and taste/statistical discrimination largely relying on theories of time allocation (Becker 1965), human capital (Mincer 1958), and taste (Becker 1957) and statistical discrimination (Phelps 1972). These theories are complementary and difficult to distinguish empirically. In spite of this, a whole set of empirical literature has developed, focusing on the direct impact of children on female wages after controlling for various human capital characteristics leaving only explanations related to productivity, preferences, and discrimination. This empirical literature is vast - Table 1 summarizes some of the studies.

\footnotetext{
${ }^{5}$ The Ukrainian revolution of February 2014 (also known as the Euromaidan Revolution or Revolution of Dignity Ukrainian: Революція гідності) took place after a series of violent events involving protesters, riot police and unknown shooters in capital Kiev that resulted in the ousting of the then-President of Ukraine, Viktor Yanukovych (https://en.wikipedia.org/wiki/2014 Ukrainian revolution ).
} 
The motherhood wage penalty is found in the USA (Anderson, Binder and Krause 2002, 2003, Baum 2002, Budig and England 2001, Loughran and Zissimopoulos 2009, Gangl and Ziefle 2009, Miller 2011, Taniguchi 1999, Waldfogel 1997; 1998), in Britain (Waldfogel 1995, 1998a, Viitanen 2004), Canada (Drolet 2002), Germany (Buligescu et al. 2009), Australia (Livermore, Rodgers and Siminski 2011), and France (Davies and Pierre 2005, Meurs et al. 2010). The estimates range from two per cent (Baum 2002; Loughran and Zissimopoulos 2009) to nine per cent (Waldfogel 1995, 1998) per child. Some studies observe rather high (up to 20\%) wage penalty per child (Kunze and Ejrnaes 2004). However, studies in Denmark (Gupta and Smith 2001, Simonsen and Skipper 2006; 2012) and Sweden (Albrecht et al. 1999) find that motherhood has little or no direct effect on wages. Generous parental leave programs and powerful labor unions are thought to be related to such findings. For example, in Sweden mothers are paid up to $85 \%$ of their salary during maternity leave.

Some researchers have undertaken cross-country comparisons of motherhood wage penalties. Analyzing surveys (1999 - 2000) for eight industrialized countries, Sigle-Rushton and Waldfogel (2007) conclude that mothers in Nordic Countries (Norway, Finland, Sweden) at age 45 earn $82-89 \%$ of what non-mothers earn. At another extreme, earnings of mothers in the Netherlands and Germany amount to 56-74 \% of non-mothers'. The United Kingdom is closer to Continental Europe, with 67-75 \% of non-mothers' earnings, while other AngloAmerican countries, USA and Canada, are more similar to Nordic countries at $81-89 \%$. Abendroth et al. (2014), using data from 13 European countries (1994-2001), find that women in the countries with higher public expenditures on childcare experience a lower motherhood wage penalty because childcare availability makes women less likely to switch to more flexible but lower-paid jobs following motherhood.

Ideally, one would want to separate discrimination from other, more "legitimate", reasons for differences in wages, such as decrease in productivity due to the effort allocation and change in preferences. However, the few attempts to do this are neither conclusive nor generalizable to the general population. Empirical testing of the effort allocation hypothesis is rather difficult due to the lack of cases when productivity can be directly measured. In professional sports, however, earnings are determined by performance: that is, by productivity. Kalist's (2008) study of The Ladies Professional Golf Association shows that, indeed, productivity of women starts falling as soon as they become mothers. On the contrary, no significant difference is found between mothers and non-mothers in academia in terms of publishing (Cole and Zuckerman 1987, Fox 2005). 
In addition to the listed explanations, mothers may search for jobs with special amenities, and therefore may agree to lower wages. The study by Kalleberg et al. (2003) shows that mothers are more likely to end up in part-time and temporary jobs that offer lower wages and no pensions and health insurance. Moreover, part-time employment was found to be a major determinant of lower wages among mothers in the US (Budig and England 2001) and in the UK (Joshi et al. 1999). Felfe (2012) states that the motherhood wage penalty may be explained by adjustments in the work schedule following motherhood, such as a change in number of hours worked, switching to a more flexible schedule or to the jobs with lower levels of stress. Waldfogel (1998) and Phipps et al. (2001) illustrate that those women who do not change employer after becoming a mother experience a lower motherhood wage penalty.

With a global upward trend in the age at first birth, researchers started investigating the impact of delaying birth on human capital accumulation and wages. Pregnancy in young years lowers investment in education (Fletcher and Wolfe 2008, Lang and Ashcraft 2013) and experience. Mature motherhood, while having a less severe impact on education (Blackburn, Bloom and Neumark 1990), still leads to shorter work experience. Therefore, career interruptions for females who have accumulated sufficient work experience before becoming mothers imply higher opportunity cost of time out of the labor market (Anderson, Binder and Krause 2002). Miller (2011) finds that each additional year of motherhood delay is associated with a 9\% increase in earnings per year of delay. Amuedo-Dorantes and Kimmel (2005) investigate the importance of education and delaying childbirth in the US and find that college-educated women who delayed motherhood beyond 30 earned $21 \%$ more than nonmothers.

Performance of mothers in labor markets in the CIS countries has not received enough attention so far. Only few tangentially relevant estimates are available. Gerry, Kim and Li (2004) examine the gender wage gap in Russia using the Russian Longitudinal Monitoring Survey and find 27\% average gender wage differential for the period 1994-1996. However, the gap became wider after the financial crisis of 1998. The difference in wages of mothers and childless women in Russia comprised nearly 8\% (Arzhenovskiy and Artamonova 2007) in the year 2003 to2005. Another Ukrainian neighbor, Poland, is shown to be the only country in the European Union without gender wage differential (O'Dorchai 2008). The same study illustrates the motherhood wage penalty in several other countries: it ranges from $1 \%$ in Poland, Greece and Hungary to $12 \%$ in Estonia. We are not aware of a single paper on the performance of mothers in Ukrainian labor market. In Ukraine the gender pay gap was $41 \%$ 
in 1991 and fell to 34\% in 2003 (Ganguli and Terrell 2005). This finding indicates potentially high motherhood wage penalty as the differential is averaged across all women: mothers and childless women.

Not surprisingly, such a wide range of estimates for the motherhood wage penalty across countries and time periods provoked further investigation of the factors explaining such a variation. Most recent literature has focused on family policies introduced in most industrialized countries over the course of $20^{\text {th }}$ century, finding support for the hypothesis that the cost of generous maternity protection policies is passed onto women through lower wages (Ruhm 1998, Gangl and Ziefle 2009). Budig, Misra, and Boeckmann (2012) conclude that family policies reduce the motherhood wage penalty when combined with cultural norms supporting maternal employment. But when the cultural support for maternal employment is low, such policies may lead to higher motherhood wage penalties.

This paper contributes to the literature in three ways. First, it is the first study to produce the estimates of the motherhood wage penalty for one of the largest post-Socialist countries, which is comparable to the estimates for other countries. Second, we investigate the role of education and postponement of fertility decisions in reducing the motherhood wage penalty - crucial for informing policy makers in their search for measures to tackle the continuing population decline and lowest low fertility in the country facing depopulation. Third, by placing these estimates into the context of existing institutions and cultural norms and comparing the evidence to other countries, we are challenging earlier findings and raising questions for further research on the impact of institutions and cultural norms on the motherhood wage penalty.

\section{Formal and informal institutions affecting fertility in Ukraine}

To set the stage for an informed discussion of the findings, in this section we offer a description of the relevant policies in Ukraine and review the evidence on cultural norms and existing practices in labor markets with respect to women, and mothers in particular. While a formal consideration of the family-related and anti-discrimination policies in Ukraine shows an advanced state of affairs suggesting family-friendly workplaces, the situation in reality is far removed from what it is on paper. Discriminatory employment practices combined with negative attitudes towards maternal employment in an environment where childcare is cheap but scarce and of low quality, and legal institutions which are corrupt and thus incapable of 
offering the protection of declared rights, put women into an extremely vulnerable position when trying to combine career and family.

\subsection{Labor Market Policies.}

The Labor Code of Ukraine originates from the Soviet Labor Code adopted in 1971, which was based on the idea of workers being a "weaker party" and, thus, requiring greater protection by the state. De jure, the Labor Code, along with a number of the ILO Conventions ratified by the country and various Cabinet of Ministers' labor regulations, declare many employee protections not common in the market economies governing wages, leave, the right to collective bargaining, and termination of employment, among others. Although the Labor Code awaits replacement in order to combine all the labor market regulations in one place and fulfill EU requirements, the current combination of regulations establishes the legal equality of men and women, including equal pay for equal work. Moreover, the current Labor Code contains a whole chapter on special treatment of women, such as prohibiting work in some dangerous and harmful occupations, forbidding pregnant women and women with small children (under age 3) from working at night, overtime and on weekends, as well as regulating leave of absences related to pregnancy, childbirth and child caring (Ganguli and Terrell 2009).

Prior to 1991, working mothers were able to use paid leave due to pregnancy and childbirth for as many as 112 calendar days. Females who gave birth to two or more children or experienced complications were entitled to 126 days of paid leave. Employers were to pay $100 \%$ of an average monthly wage during this time interval. Voluntary leave for up to one year was possible only for those who had working experience of more than one year, and during this period mothers could get only partial compensation. In the independent Ukraine, fully compensated periods were prolonged to 126 and 140 days respectively. However, responsibility for paying maternal leave compensation was shifted to the Fund for Social Protection, contributions to which are paid via the social insurance system as part of payroll tax. But that also meant that only insured women were eligible. Voluntary leave was extended to two years in 1991, and since 1998 this period has been fixed at three years with partial compensations, or even without in some cases. 


\subsection{Baby Bonus policy}

In spite of the complexity of the fertility decision mechanisms, the one and only pronatalist policy pursued by the Ukrainian government has been the so-called baby bonus. ${ }^{6}$ This bonus over the course of 1990s had been set at an extremely low level, but has been increased several times to a considerable degree over the course of 2000s. Table A.1 shows the evolution of this policy. From 2008, the amount of the baby bonus increased for each subsequent child. In 2014, the government changed the approach, and now the amount of the baby bonus does not depend on the birth order. Now new mothers are entitled to a bonus of UAH 41,280 (USD 1720). The first payment is currently UAH 10,320 (USD 430) while the rest is paid in equal monthly installments over the period of three years.

\subsection{Cultural norms with respect to maternal employment.}

Among European countries, Ukraine has one of the highest proportion of people strongly disapproving of women with children younger than 3 years old working full time. According to the Analytical Research on Women's Participation in the Labor Force in Ukraine, $25 \%$ of Ukrainians share such view. ${ }^{7}$ The stereotype that women's primary role is motherhood and therefore they should "sacrifice" their professional and career interests for the sake of the child is more common in Ukraine compared to other European countries. At the same time, less than $4 \%$ of Ukrainians do not approve of fathers with children under three years old working full time, while the proportion of people who completely approve of this is one of the highest among European countries (over 40\%). This emphasizes the cultural perceptions about the "appropriate" model of a family, in which a man and a woman have different roles based on gender. The evidence from the World Values Survey reveals that Ukrainians believe that the woman's role is at home. Figure 3 shows that more than a half of Ukrainians agree or strongly agree with the statement "Being a housewife is just as fulfilling as working for pay". Moreover, Figure 4 suggests that around 35\% of Ukrainians agree with the statement that children suffer when their mother works.

Not only the perception of working mothers in society but also the availability of alternative childcare arrangements influence the possibilities for combining work and family. According to Jappens and Bavel (2012), grandparents are the vital part of informal childcare arrangements in Europe. It is particularly the case in Eastern Europe, where the family norms

\footnotetext{
${ }^{6}$ http://en.wikipedia.org/wiki/Baby bonus

${ }^{7}$ http://www.idss.org.ua/monografii/2013 en womens\%20participation.pdf
} 
include mutual exchange of support between parents and children who live in separate households. Besides, according to Ukrainian legislation, the mother, father, grandmother, grandfather or other family member have a right to take child care leave until the child turns three years old. Intensive involvement of grandparents decreases the cost of employment for women, although it may restrict employment to part-time due to the inability of grandparents to provide full-time childcare. Results from a relatively recent survey confirm heavy involvement of the older generation in providing childcare in Ukraine: only $23.4 \%$ of families reported no support with childcare from grand-parents, whilst almost 38\% reported substantial support (IDSS 2009).

\subsection{Government childcare system in Ukraine}

Preschool education in Ukraine is included in the state educational system and is the responsibility of the Ministry of Education. The two major types of preschool facilities are nursery schools (dytyachi yasla), which care for infants from six weeks to three years old, and kindergartens (dytyachi sadki), which are intended for children from three to six years of age.

Provision of publicly subsidized childcare may not be as effective in Ukraine as in other countries. Although state childcare facilities are relatively cheap (according to the Ukrainian Statistics Agency, these expenses are reported as part of the "Education" category and over 2002-2014 families spent on it on average 1.1-1.3\% of the household budget ${ }^{8}$ ), it is of lower quality. In the USSR time, the majority of the child-care facilities belonged to particular enterprises. The bankruptcy or poor financial state of these enterprises during early years caused a significant decrease in the number of available childcare facilities. Currently, there is a documented shortage of childcare places: about 30 children are put on a waiting list per 100 admitted (Sologoub, 2013).

\subsection{Existing employment practices in Ukraine: Treatment of Mothers in Labor Markets}

Despite the existence of family-friendly national labor policies and antidiscrimination laws, there is some evidence of discrimination practices in the Ukrainian labor market. Although most of these facts are based on qualitative research or case studies, they might further enhance understanding of the magnitude of the motherhood wage penalty in Ukraine.

\footnotetext{
${ }^{8}$ http://www.te.ukrstat.gov.ua/files/VRD/VRDO.htm, http://www.ukrstat.gov.ua/
} 
Hiring practices. According to the Labor Code, employers are not allowed to mention characteristics not related to the professional skills and competencies of potential employees in a job advertisement. However, the content analysis of most popular hiring websites shows that employers violate this regulation. For example, one financial company is looking for "HR-director, men under 35" while another company is looking for "women of age 40 onwards for the administrative work". 9

Contracts. HR specialists argue that some employers have a clause in the labor contract that obliges women not to get married or/and pregnant during first two or three years of employment. If she does, she is liable to face monetary penalties. For example, according to the State Labor Inspection conducted in October 2012 (audit of 2500 firms), more than 900 labor law violations were documented. Most of them related to the delayed payment of childcare benefits to female employees, involvement of pregnant women and women with children under 3 years in the types of work prohibited by law, and non-payment of sick leave. ${ }^{10}$

Poor enforcement of the Labor Code. Although the Labor Code prohibits layoffs of pregnant women and women with small children, human rights activists claim that the lack of effective sanctions for the violation of these rules "unleashes" employers. ${ }^{11}$ The basic antidiscrimination legislation in Ukraine was passed in 2010, but the State Program on Equal Rights of Men and Women was approved only in 2013. ${ }^{12}$ Delayed approval of the Program, along with the 2010 Administration reform, prevented the implementation of the basic antidiscrimination law. ${ }^{13}$

Pregnancy tax. Extensive motherhood benefits in Ukraine may actually work against mothers, leading to "positive discrimination" (Einhorn 1993). One example is the new 2013 Law "On Amendments to Certain Legislative Acts of Ukraine regarding Pensions". According to this law, maternity leave is now included in the insurance period and therefore the employer is required to pay a new tax to the Pension Fund for each employee on maternity leave. This tax, which accounts for $33 \%$ of salary, will discourage employers from hiring

\footnotetext{
${ }^{9}$ http://tyzhden.ua/Society/78512.

${ }^{10}$ http://helsinki.org.ua/index.php?id=1362661718\# ftn34

11 http://helsinki.org.ua/index.php?id=1398060713

12 http://zakon4.rada.gov.ua/laws/show/717-2013-\%D0\%BF

${ }_{13}$ http://helsinki.org.ua/index.php?id=1398060713
} 
pregnant women and potential mothers. And in cases where they are hired, women will most likely only be paid the minimum wage. ${ }^{14}$

\section{Methodology}

As is conventional in the motherhood wage penalty literature, we start with female wages determined by the human capital model:

$$
\ln W_{i t}=\beta_{0}+C_{i t} \delta+\mathbf{X}_{\mathrm{it}} \boldsymbol{\beta}+\left(v_{i}+u_{i t}\right),
$$

where $W_{i t}$ is hourly wage rate of an individual $i$ in year $t, C_{i t}$ is a set of variables describing a woman's motherhood (e.g. ever mother, number of children, one child, two or more children, number of children in different age categories), $X_{i t}$ - vector of explanatory variables, $v_{i}$ individual specific time invariant unobserved characteristics (ability, morbidity, etc.) and $u_{i t}$ - idiosyncratic error. Following the previous literature, explanatory variables include mother specific characteristics that have an impact on her labor market outcomes, such as mother's education, marital status, age, and actual experience. ${ }^{15}$ In addition, we explore the impact of firm-specific characteristics, such as size and ownership of the firm, as well as women's parttime job status, and share of experience in large firms.

We estimate Equation (1) by fixed effects, which has a number of desirable statistical implications in the analysis of the impact of the event of motherhood on women's wages. Explicitly dealing with the person-level error ensures that the impact of unobserved timeconstant factors affecting women's wages (such as ethnicity, early labor market and family experiences, as well as temporally stable attitudes and preferences) are accounted for by the model. In removing all time-constant differences between women, the fixed-effects (FE) estimator effectively identifies the effect of interest from within variation exclusively. In other words, it produces the estimate of the effect of a change in the number of children on the following change in women's wage. Furthermore, the FE estimator also permits a correlation

\footnotetext{
${ }^{14}$ http://www.unian.ua/society/817662-zmi-noviy-podatok-na-vagitnist-uskladniv-stanovische-jinok-naroboti-video.html

${ }^{15}$ We have also originally included tenure and time out of the labor market. However, because of our preferred fixed effect specification and annual observations, it seems that the actual labor market experience measured in months completely describes the woman's labor market involvement.
} 
between the person-level error, $v_{i}$, and observed covariates (Wooldridge 2002) as, on the contrary to the random effects estimator, it completely eliminated this error component. This addresses our concerns for potential selection of women into motherhood by any unobserved, but economically relevant, characteristics.

As we are dealing with the sample of working women only, we have to address the issue of self-selection into the labor market. The traditional approach to correct for selfselectivity bias due to not observing information about wages of non-working women is the Heckman sample selection model (Heckman 1979). The idea is to include the inverse Mill's ratio as an additional explanatory variable into the regression. The inverse Mill's ratio is computed based on the probit regression of the probability of women's participation in the labor force:

$$
h_{i t}=\mathbf{Z}_{\mathrm{it}}^{\prime} \beta_{2}+\varepsilon_{2 i},
$$

where $h_{i}$ is an indicator equal to one if a woman is employed and zero otherwise. To test if sample selection bias exists, the relationship between the residuals for the two equations (1) and (2) should be examined. If the unobservables in the employment status regression model are correlated with the unobservables in the wage regression, then the estimates of the wage equation without correction would be biased.

In many applications, sample selection and individual specific unobserved heterogeneity issues occur simultaneously. Some estimators have been proposed which deal with both sources of estimation bias, producing consistent results under different assumptions. Wooldridge (1995) proposes an estimator that requires specifying the functional form of the conditional mean of the individual effects in the equation of interest. The other two estimators impose some distributional assumptions on the error terms (Rochina-Barrachina 1999) and the fixed effects (Kyriazidou 1997) in the equation of interest. Dustmann and RochinaBarrachina (2000) apply the three methods mentioned above to the estimation of the wage equation for female labor market participants, verifying the impact of actual labor market experience on wages. The authors also offer extensions of these estimators to address other econometric problems, such as non-strict exogeneity and/or time constant non-linear errors in variables. Given data availability, we use the estimation procedure proposed by Wooldridge (1995). Selection equation is estimated following the Chamberlain's random 
effect probit model, where $Z_{i}=\left(Z_{i t}, \bar{Z}_{i}\right)$. Then the inverse Mill's ratio is added to the fixed effect estimation using a selected sample of employed women.

One of the major concerns in most studies of the effect of children on labor market outcomes for mothers is endogeneity of such explanatory variables as marriage, motherhood, experience and tenure in the wage equation. Korenman and Neumark (1990) explore these econometric issues in a cross-sectional analysis of marriage, motherhood and earnings. They perform their analysis using 1968 National Longitudinal Surveys. Their main findings are that the OLS estimator is biased mainly because of the unobserved individual specific heterogeneity, and they find evidence that experience and tenure are endogenous while marital status and number of children are exogenous in the wage equation. Moreover, in their research standard sample-selection estimation shows no evidence of selection into labor market bias. They find a $7 \%$ wage decrease for one child and $22 \%$ for two or more children. The authors suggest that family background variables such as parents' occupation and parents' years of education or level of education of the mother can be used as instruments for experience and tenure in a cross-sectional setting.

Taking into account the above considerations we would, like to compare the estimates from the following models: (i) Pooled OLS, (ii) OLS corrected for selectivity into labor market, (iii) FE estimation, and (iv) FE estimation corrected for selectivity into labor market. For the selection equation, we include a dummy variable of whether the woman has an infant child, so $\mathbf{Z}_{\mathrm{it}}=\left(X_{\mathrm{it}}, I_{\mathrm{it}}\right)$. Controlling for the number of children, this should have no effect on the wages, but has a substantial effect on the labor force participation decision.

In addition, as suggested by the literature, we will explore the heterogeneity of the motherhood wage penalty along the following dimensions: education, age at first birth, firms' characteristics, and marital status.

\section{Data}

For the investigation of the impact of childbearing on mothers' labor market performance in Ukraine we analyze panel data from the Ukrainian Longitudinal Monitoring Survey (ULMS). The sample consists of three waves of the ULMS, which is a nationally representative sample of Ukrainian households in 2003, 2004 and 2007. The first wave of the survey was administered in 2003 and contains 4,056 households/8,621 individuals. The 
ULMS household questionnaire contains information about the structure of the household, housing conditions, household assets, income and expenditure. The ULMS individual questionnaire contains information on individual characteristics of household members, individuals' main and additional jobs, non-employment periods, main and secondary jobs in a reference week, unemployment and job search in the reference week, education and skills, changes in residence, attitudes, health and ecology. Additionally, the 2003 ULMS individual questionnaire contains retrospective data on job characteristics in 1986, the year of Chornobyl catastrophe; 1991, the year in which Ukraine became independent; and for the period from 1997 to 2003. Information about the main job has been taken from both retrospective and reference week sections.

\subsection{Sample construction}

Using both the reference week data and the retrospective information, we construct a panel data over the period from 1997 to 2007, and restrict it to female respondents aged between 15 and 65 in 2003. There are three important concerns which led us to the exclusion of earlier years from the retrospective data. Firstly, there is an issue of the survival bias, because the data for 1986 and 1991 has been obtained from the retrospective section of 2003 questionnaire. It means that samples for these years are not representative due to the absence of older people. In some other studies using the ULMS data set, authors weighted the 1986 and 1991 samples using weights for 2003 and the information on the age and gender structure from 1987 and 1991 Statistical Yearbooks of the USSR (Gorodnichenko and Sabirianova 2004, Ganguli and Terrel 2005). Second, 1986 wages are reported in USSR roubles, and 1991 wages in coupons, which need to be translated to real terms, of course. There is rather precise information about inflation for the years 1997-2004, ${ }^{16}$ while inflation for 1986, 1991 and 2004 is hard to measure correctly. Moreover, the basket of goods and services for the calculation of the CPI changed several times during this period. Finally, and most importantly, this is related to the accuracy of the construction of our variables of interest - number of children, which will be discussed in more detail further.

The data set contains information on the person's job characteristics ${ }^{17}$ as well as contractual monthly wages in December of every year, except for the interview years when

\footnotetext{
${ }^{16}$ Consumers Price Index (CPI) available from the State Statistical Committee of Ukraine (http://www.ukrstat.gov.ua) will be used as a measure of inflation.

${ }^{17}$ We use information on main job only, because the labor market history does not go back to 1986 for secondary jobs. However, as we are focusing on the hourly wage rate, the number of jobs (even if different between mothers and nonmothers) should not affect our conclusions.
} 
the information is taken from the reference week. Thus we chose December as our reference time for the construction of the pseudo-panel. In addition, we have full employment history, starting from 1986, which is used in constructing actual work experience in months, and time out of the labor market, and a set of job- and firm-specific characteristics. We also know when the first job started, and the start month and year of the job which the person held in 1986. Thus our measure of experience is bound to a measurement error due to labor market interruptions for those people who were out of the labor market between their first job and the job they held in 1986, and for those who were not employed in 1986 for the time prior to the start of this non-employment spell. However, there are two reasons why we think that this limitation has minor consequences for our analysis. First, due to peculiarities of the organization of labor in the Soviet Union, non-employment spells are unlikely to be common prior to 1986, even prior to 1991. Second, as we rely on the fixed effect approach, our estimates are based on the variation within the sample period, i.e. year to year changes in experience after the start of the sample in 1997, with all the prior differences being irrelevant.

The ULMS data set allows constructing a data set for females that contains 53,119 person-year observations, 44,564 of which are of working age (15-65 years old). For 42,647 of them we have work status available, and only 17,221 person-year observations are for employed women with reported wages. The final pooled data set contains 15,656 observations, which is approximately 1,423 observations per year.

Hourly wages. We use nominal monthly contractual wages in December of every year, except for the interview years, and current contractual monthly wage in the interview month, currency in which wages were paid with the corresponding exchange rates, and the $\mathrm{CPI}$ to convert all wages to real monthly wages expressed in UAH. Hours worked are derived from the employment history where people were asked whether they worked always full-time, always part-time, or a combination of the two. In the first two cases, we have the actual number of working hours per week over the entire work spell. For the latter, we have three periods of part-time work, so we are able to populate corresponding periods with appropriate working hours. To avoid a division bias, we follow the procedure suggested by Kimmel and Kniesner (1998): real monthly wage is divided by 40 if a person reports that she works not less than 25 hours per week and divided by 20 if she works less than 25 hours per week. The obtained values must then be also divided by the average number of weeks in a month (52/12). 
Children. ULMS does not have explicit retrospective information on children. As the fertility history questions are poorly defined in the survey, ${ }^{18}$ we construct our children-related variables from the household roster. Of course, it does have some limitations. For example, we are bound to assume that the biological child living with the mother in 2003, 2004, and 2007 has lived with her all the time since birth. On the other hand, if a woman does not have a child living with her at the time of the interview, she will be treated as a non-mother. Given that we are less likely to have children older than 18 present in the household at the time of interview and the fact that the motherhood wage penalty dissipates over time (Viitanen 2014, et al. 2014), we restrict our measures to children 0-18 years old. Yet this approach has important advantages given the question we are aiming to answer: if the woman does not have children living with her in the same household, there is no reasonable explanation on why the motherhood wage penalty could manifest itself.

\subsection{Sample Description}

Table 2 presents the descriptive statistics for females for the first and last year of the sample and for the pooled data. Comparing 1997 to 2007 data shows that the proportion of employed women has not changed much, while the share of those married increased from $58 \%$ to $63 \%$. Likewise, the real wage has grown from UAH 383 at the beginning of the sample period to UAH 800 at the end.

Focusing on the characteristics of the pooled sample in Columns (5)-(6) reveals the following. Approximately $47 \%$ of females in the sample do not have children, ${ }^{19} 33 \%$ have only one child, $18 \%$ have two children, and only $3 \%$ have more than two children. Employed women account for $53 \%$ of the entire sample, have on average more children and are more likely to be married compared to the whole sample. The latter may be explained by the fact that employed females are usually older than the rest of the sample. Employed women are also better educated: while high school, professional and higher education groups constitute $40 \%, 45 \%$ and $15 \%$ of the whole sample, respectively, the shares of the two latter categories are much higher for employed females (53\% for women with a professional and $22 \%$ for women with a higher level of education). We also find that the average wage is UAH 428 measured in constant 2007 prices.

\footnotetext{
${ }^{18}$ We do not know whether the child whom the woman gave birth to is still alive, and if not, when (s)he died (this information is only explicitly asked for children born in 2005-2007, but not prior).

${ }^{19}$ Through all this paper a child is a person aged between 0 and 18 years old who lived in the household with a particular female, not necessary her own children, or her own children of any age.
} 
Table 3 allows for the comparison along two dimensions: employment and motherhood status. Although there are more current mothers among employed (53\% in the whole sample vs. $67 \%$ among employed), there is neither a significant difference nor a specific pattern in the number of children (both overall and by age groups) and age at first birth among working mothers (Columns (3)-(4)). The average age at first birth is 22-23 years and is the same for mothers and non-mothers. The reason why non-mothers have non-missing age at first birth is that we define mother as a woman who has children of age 0-18 in the current period. Therefore, non-mothers include both childless women as well as women with children older than 18 years. Comparing information on mothers and non-mothers in the sample of employed women (Column (4) vs. Column (6) in Table 3) shows that mothers are on average older, slightly better educated, $25 \%$ more likely to be married, and have on average two more years of experience. With respect to the monthly wage rate, it is lower for mothers (UAH 412) than for non-mothers (UAH 460), while both groups on average work the same number of hours. In terms of hourly wages - our dependent variable - mothers earn slightly less than non-mothers ( 2.45 vs. 2.70 per hour), but the difference is statistically significant.

Although the descriptive analysis does show some evidence for the differential hourly wage rate between mothers and non-mothers, this is just a crude comparison. Controlling for various demographic and human capital characteristics, as well as taking care of the unobserved heterogeneity and sample selection, may reveal a completely different relationship. The next sections presents the results from the multivariate analysis of the relationship between motherhood and wages.

\section{Results}

\subsection{Estimation of the motherhood wage penalty}

Estimates from the basic model for working age females (15-65 years old) are shown in Table 4. Explanatory variables of interest are dummy variables for number of children (018 years old) in the household. Mothers with no children 0-18 years old are treated as controls (omitted category). The estimated motherhood wage penalty from the pooled OLS regression (Column 1) is $7.8 \%$ for those women who have one child and $12 \%$ for those with two or more children. As expected, there is a positive, albeit decreasing, effect of age and actual experience. Comparing vocational/professional training (2-3 year) to university education (56 years), the former brings much smaller returns per year of study: $\sim 4 \%$ compared to $\sim 7 \%$. The estimated effect of being married is not statistically significant compared to those who 
are divorced/widowed/separated, but those who have never been married enjoy an $11 \%$ premium in wages.

The sample we use includes only those individuals for which we observe wages, i.e. employed individuals, which might produce biased results (Heckman 1979). For example, a woman who is less productive in the job market, but more productive in the household, will face lower wages and will be more likely to have more children. So these women choose not to work. Not taking them into account may lead to underestimation of the motherhood wage penalty (find it being less negative). Column (2) presents the second stage results from the Heckman Selection procedure. The Inverse Mills Ratio comes from the first stage based on the probit regression of female participation in the labor market with the same explanatory variables as in the OLS regression, plus a dummy for the presence of an infant in the family (Verbeek 2008). After adding the inverse Mills ratio into the pooled OLS regression, the estimated effect of children almost does not change. Moreover, the coefficient of inverse Mills ratio is insignificant. That means that there is no evidence of a sample selection bias, which is consistent with the findings in Gupta and Smith (2001), Waldfogel (1998), and Korenman and Newmark (1990) for the cross-sectional settings.

Heterogeneity bias. The OLS and Heckman Selection Procedure allow controlling only for observable characteristics, while there might be individual specific time invariant unobserved characteristics (such as ability, work-related preferences, willingness to work, etc.) that also have an impact on females' wages. As a result, the OLS estimates may be biased because of other omitted variables. We exploit the panel nature of the data and turn to the fixed effects procedure to account for the time invariant unobserved individual heterogeneity. Results from this regression are provided in Column (3). The coefficients on variables of interests are of the expected signs and statistically significant. The negative effect of having one child is almost $16 \%$, and that of two or more children is $27 \%$. With respect to human capital characteristics, returns on education are estimated to be of $31 \%$ for higher education and $12 \%$ for vocational/professional education, which brings them to approximately the same $6 \%$ per year of studies. The effect of marital status variables becomes much smaller and jointly insignificant. The formal F-test suggests that the null of whether all unobserved individual specific variables equal to zero is rejected $(F(2855,12789)=8.48$, Prob $>F=0.0000)$. In addition to theoretical justifications for the appropriateness of the fixed effect procedure, 
we have run a formal Hausman model specification test of fixed effects versus random effects, which has suggested that random effects is not appropriate (chi-sq statistics $=2530.92) .{ }^{20}$

Heterogeneity bias and selection into labor force. Although the test with the OLS model has provided no evidence of selection bias, this may be different in the panel setting. Therefore, we apply a sample selection correction procedure to the fixed effects estimator (Wooldridge 2002, Chapter 17.7) in order to address the issue of the bias associated with self-selection into labor market controlling for unobserved individual heterogeneity. Column (4) of Table 4 presents results from the fixed effect estimation with an additional term - "lambda" (Inverse Mills Ratio). IMR is estimated from Chamberlain's random effect probit model, with the same explanatory variables as in the fixed effect regression adding dummy variable for the presence of infant in the family and all averages (within individual) of all variables involved. The coefficient of "lambda" is positive and significant, which means that there is a positive selection bias in fixed effects estimation of log wage equation. From this model, if a woman has only one child 0-18 years old living with her, she has $17 \%$ lower wages after controlling for the human capital characteristics and labor market experience, while having two or more children has doubled the effect to $30 \%$. However, one has to bear in mind that the average number of children in the sample of employed mothers is 1.44 , which means that the high $30 \%$ estimate should be treated with caution, although this is still within the range of previous estimates from 0 to $33 \%$ (Viitanen 2014). Since this specification allows for addressing both individual time-invariant heterogeneity as well as selection into the labor market, we will use it for further tests as a preferred specification. ${ }^{21}$

Other tests. To explore heterogeneity of motherhood wage penalty along several other dimensions we run the preferred specification (as in Column (4)) including additional controls and interactions. The full results from the analysis with firm-specific characteristics

\footnotetext{
${ }^{20}$ Both fixed effect and first difference estimators address the problem of unobserved heterogeneity bias in case when this unobserved effect is correlated with one or more explanatory variable and both are asymptotically efficient but under different assumptions. First difference estimator is the most efficient under the assumption that error term follows random walk, while fixed effect estimator is more efficient under the assumption of strict endogeneity of explanatory variables. In many cases, the truth is likely to be somewhere in between. The results of fixed effect and first difference estimation are found to be similar.

${ }^{21}$ Although Korenman and Neumark (1990) raise concerns about endogeneity of human capital characteristics, such as experience and tenure (Korenman and Neumark 1990), they refer to the cross-sectional setting and emphasize the role of the unobserved individual heterogeneity. Korenman and Neumark (1990) implement their research for the crosssectional data and suggest family background variables (occupation and education of parents, dummy of whether individual lived with parents at the age of 18 , etc) as instruments. All proposed instruments are time invariant variables. Therefore they cannot be used for the panel data estimation. In the case of panel data, such family background variables as husband's/partner's years of education, experience, and tenure can be used as instruments for female experience and tenure (Mroz, 1987). However, it restricts the sample to married females. In addition, in the ULMS data set information about partners is available only for half of married females, and the marital history part of the questionnaire after 2003 is not complete, as we do not know whether any specific marriage ended and when.
} 
are offered in Column (5) of Table 4, but the other specification will only be mentioned in this sub-section with the full set of results available upon request.

First, adding firm-specific characteristics makes the estimated coefficients of interest slightly smaller (Column (5)). However, only an indicator of whether the woman works for either state, public enterprise, or a collective farm returns a statistically significant effect of approximately $12 \%$ lower wages. Neither the dummy for the part-time work nor for the size of the firm have statistically significant effects, although the direction of the effects is as expected.

Second, we also explore a hypothesis that the motherhood wage penalty is different for women working at firms of different size and/or ownership. We found no differential impact of children on wages by firms' characteristics. However, adding the interaction terms changed the significance of the main estimates, with women in small firms and state/public/collective ownership earning lower wages.

Being aware of the limitations of using children measures based on the information from the household roster, we have included the dummy for ever-giving birth to a child from the fertility history to separate women who gave birth but have not lived with the child from non-mothers. The results produced for the variables of interest turned out to be very close to the ones in the main specification.

Finally, similar to Budig and England (2001), we examine whether the wage penalty for motherhood differs for married and non-married mothers. To test this, we include interaction of the number of children and an indicator for being married to the preferred specification. Contrary to Budig and England (2001), we find that married mothers experience lower motherhood wage penalty compared to non-married mothers. The latter may be explained by the fact that married women have a spouse to share parenting responsibilities with and, as a result, can be in a better position to combine work and family. Further analysis shows that this finding is driven by the effect of having two children or more, with no differential impact of marriage on the motherhood wage penalty for the only child.

\subsection{Various measures of children variables}

Panel $\mathrm{A}$ in Table 5 presents the results from the main specification using various measures of motherhood. Column (1) shows the average wage penalty for currently being a mother of $0-18$ year old child(ren) is $18.51 \%$. The wage penalty for each additional child is 
equal to $15 \%$ (Column 2). Column (3) provides the results for the coefficients of interest from the most preferred specification.

Column (4) of Table 5 distinguishes the effects of children of different ages. As can be seen, the penalty grows with the age of the child: being almost twice as large per child of school age (7-18) as it is for the pre-school age children. ${ }^{22}$

As mentioned before, the motherhood variables used in the main analysis are constructed from the household roster. Therefore, these variables suffer from the limitation of putting mothers whose children are older than $18 \mathrm{and} /$ or are not living with them at the time of interview in the same control group with women who have never been mothers. To address this concern, we introduce a dummy variable for whether a woman has children older than 18 years. On the one hand, this helps us to better define the control group - only nonmothers. On the other hand, it allows us estimating the effect of having older children on wages. As shown in Panel B of Table 5, introduction of this variable has no sizeable effect on the coefficients of interest, while the impact of having older children is not statistically significant and is very small in magnitude.

Earlier in the paper we mentioned that our approach produces estimates of the differential pay between mothers and non-mothers which can be consistent with both the productivity related explanation and that of statistical discrimination. Following Waldfogel (1997), we have restricted our sample to women aged 45 years or younger in 1997. The reason for doing this is to estimate the penalty for women of childbearing age only. Although we lost one third of the sample, the significance of all coefficients of interest is preserved, although the magnitude is smaller. In this sample, both treatment and control group are potential subjects of statistical discrimination. Therefore, the estimates of the wage gap between mothers and non-mothers should mostly be related to productivity and preferences, and less so to discrimination. Indeed, as can be seen in Panel C of Table 5, the estimated motherhood wage penalty from this sample is almost twice smaller than that in Panel A. Consequently, one may conclude that approximately half of the motherhood wage penalty is attributable to discrimination channels.

\footnotetext{
${ }^{22}$ Being concerned with the fact that the presence of children in the sample is constructed from the retrospective part of the ULMS without formal information on the presence of the child in the household over the period from 1997 to 2003, we have performed a test focusing only on the two years of the ULMS data. Unfortunately, FE estimations have not resulted in any meaningful estimates mainly due to the fact that over the course of one year very few women have given birth to a child. Therefore, while acknowledging the weakness of our approach, this is the best a researcher can do to address the question.
} 


\subsection{The motherhood wage penalty and education}

An interesting question that arises after investigation of the wage penalty for motherhood is whether this penalty is the same for all females. For example, Anderson, Binder, and Krauser (2002) find that mothers with college education have no wage penalty after controlling for time out of the labor force. The first row of Table 6 presents the results of the estimation of the motherhood wage penalty for subsamples of women with different levels of education, as suggested in the literature. Overall, we find a similar pattern with the lower motherhood wage penalty at higher levels of education. However, it does not disappear completely for women with a university degree.

The largest wage penalty (18\%) is for those females whose highest level of education is high school or lower. Since we control for the actual labor market experience, these results cannot be explained by the claim that leaving work does not impose high costs on low-skilled workers (Anderson, Binger and Krause 2002). For those females who have completed vocational/professional education (the largest share of the sample) the motherhood wage penalty is $17 \%$, while females with at least bachelor's degree experience the smallest wage penalty at $11 \%$. The difference between the motherhood wage penalty of those with higher education and those with the lower levels of education is statistically significant at the $10 \%$ level (cell with the grey background). These results are in line with Taniguchi (1999), who found that education significantly reduces the wage penalty for females with at least 12 years of education.

\subsection{The motherhood wage penalty and timing of first birth}

Blackburn, Bloom and Neumark (1990) suggest that a delayed first childbirth is associated with higher wages. They investigate Mincerian wage equation adding age-at-firstbirth variables as additional controls. However, age-at-first-birth variables are time invariant; therefore their effect can only be estimated using simple OLS, which does not take into account unobserved individual specific effects. Moreover, age at first birth is endogenous: females who earn higher wages tend to postpone first birth. Therefore, we use our preferred specification adding interaction terms with the dummy variables for the age at first birth as controls (Taniguchi 1999). The coefficients obtained give estimates of the wage differentials between mothers who had their first birth during a certain age range and females who have no children. 
Age at first birth is drawn from the fertility history. To determine the age categories for the age at first birth, we explore the distributions, overall and across education categories, presented in Figure A1. They show that the crude birth rate in Ukraine has been the highest among 20-24 year olds. The other two prominent groups are 25-29 and 30-34. As Figure 2 suggests, fertility within these age categories has been following different trends over the past 23 years: decreasing crude birth rate among those age 15-19, and in a most dramatic way among those aged 20-24, while increasing among older women.

Column (2) in Table 6 offers the results from the analysis of how the effect of children on wages differs depending on the age at first birth. The estimated wage penalty per child is in the region of $11-15 \%$ no matter what is the age at first birth, except for the older than 30 category for which the motherhood wage penalty is the highest, at $23 \%$, contrary to earlier findings in the literature. However, the only marginally significant difference is between the estimate for the number of children at the age at first birth 25-29 and that at the age at first birth of 30 and older.

The differences are more pronounced when analyzed by educational groups (Columns (4), (6), and (8)). For example, females with high school education or lower experience a $40 \%$ motherhood wage penalty if they give first birth at the age of 30 or older, which is the highest wage penalty among the three educational groups. Women with bachelor degree or higher lose only $16 \%$, while women with professional education face a $28 \%$ wage penalty. This finding shows that education does mitigate the motherhood wage penalty, but only for those who delay the first birth until age 30 or above.

Within the groups of women who gave first birth at the same age interval, there is no statistically significant difference across educational categories, except for those who delay first birth till age 30 or above. In this group the motherhood wage penalty is more than twice smaller if a woman has higher education.

To conclude, we do find heterogeneity of the motherhood wage penalty across educational categories and depending on the age at first birth. Also there is some evidence that education serves as a mitigating factor, and this is most pronounced among women who delay childbirth until age of 30 or above. However, delaying childbirth is not bringing extra benefits in terms of lower motherhood wage penalty for those with higher education, while increasing the penalty for those with lower levels of education (contrary to the previous findings). 


\section{Conclusions and Policy Recommendations}

Facing military confrontation with Russia and dire political and economic situation, new leaders of Ukraine may have no time to think about another genuine threat, which shows no signs of reversal in the nearest future: crisis in demographics and population health. Population decline (12\% since Independence) combined with aging and health deterioration undermines any efforts to revive economic development by reducing the pool of the labor force and increasing the burden on the public sector budget because of elder-care obligations. ${ }^{23}$ One of the most prominent factors in this population decline is the low fertility, which reached the "lowest low" levels of 1.1 in 2001. In spite of the complexity of the factors influencing fertility decisions, only the baby bonus is discussed in Ukrainian policy circles as a measure to address the issue of low fertility. In spite of enormous increases in the amount of the baby bonus in the period from 2005 to 2013, there is little evidence that this has led to an increase in total fertility. At the same time, there is some indication that this policy has led to a disproportionate increase in birthrates among poor and marginalized population groups. This tendency suggests the existence of other impediments to increasing fertility, and the current paper focuses on one of them: the motherhood wage penalty. The high motherhood wage penalty may explain the ineffectiveness of the baby bonus across the population, combined with an increase in birth rates among low wage earners or those not in the labor force: the lower is one's wage, the more likely it is that the fixed amount of the baby bonus will compensate for that loss of wages.

After controlling for human capital characteristics and the unobserved time-invariant heterogeneity, such as preferences for children and individual relative productivity in the job market, the estimated motherhood wage penalty in Ukraine is quite high. In particular, the average wage penalty for being a mother in Ukraine is approximately $19 \%$. Females with only one child earn $17 \%$ less than females without children, and females with two or more children earn approximately $29 \%$ less.

Our analysis reveals heterogeneity in the estimates across educational groups, depending on the age at first birth, and with respect to marital status. Women with higher education suffer the lowest motherhood wage penalty compared to those with lower levels of education ( $11 \%$ vs. $18 \%$ per child). There is no evidence of benefit in postponing having one's first child. On the contrary, delaying first birth till age 30 and above is associated with the highest motherhood wage penalty, but only among those with the lowest levels of education.

\footnotetext{
${ }^{23}$ http://nationalinterest.org/feature/ukraines-real-crisis-demographics-health-time-bomb-11851.
} 
Moreover, women who are not married are suffering from the highest motherhood wage penalty, especially when having two or more children. The analysis of the heterogeneity of the effect suggests that the motherhood wage penalty is the highest among single women with high school education or less, who gave birth to her first child at age 30 or above, when she has two or more children $0-18$ years old.

Comparing the results from the main estimation to those obtained from the data restricted to women of childbearing age, we reach the conclusion that approximately half of the motherhood wage penalty can be attributed to discrimination, since both current mothers and potential mothers should have minimum differences with respect to the risk of being discriminated against.

While the estimate of the motherhood wage penalty of $19 \%$ is too high as for the country with relatively generous maternity leave policies, it is too low as for the country which combines these generous policies with the cultural norms opposing employment of the mothers with young children.. Based on the World Values Survey data, Figure 4 suggests that Ukrainian society is very similar to Germany regarding attitudes toward maternal employment, and therefore, we would expect the penalty to be closer to 33\% (Budig, Misra, and Boeckmann 2012). However, this is not the case. As in the equilibrium the cost of maternity leave provision is transferred almost completely into lower wages of mothers (and sometimes women in general because of statistical discrimination), the motherhood wage penalty of the magnitude much lower than that in Germany can be explained by the lack of law enforcement and poor judicial system, so that employers do not have to bear the full cost of the mandates. Evidence suggests that Ukraine has probably the most de facto liberal labor market environment, where the employers do not bear any responsibility for discriminating against women/mothers, even though there is a de jure provision for secured rights of pregnant women and mothers. This is achieved through an informal arrangement either as a promise taken at the start of a job to leave the position once a woman is pregnant, or a provision of an undated letter requesting quit at "own will", which the employer uses once the "threat of pregnancy" becomes a reality. In addition, existing cultural support for the involvement of grandparents in childcare combined with the relatively early retirement age works towards the same direction to lower the motherhood wage penalty.

A simplified comparison of the motherhood wage penalty with the size of the current baby bonus payments shows the following. The estimated $20 \%$ motherhood wage penalty applied to the average monthly wage of 3,035 UAH (December 2014) means a loss of 
approximately $607 \mathrm{UAH}$ per month. As this penalty has been estimated for the sample of mothers with children 0-18 years old, we assume that this is the period over which the penalty applies. These are the costs net of the losses through human capital channels, such as education and experience. Using the current bank interest rate of $15.6 \%$ per year, the net present value of the motherhood wage penalty over 18 years is UAH $44,394^{24}$ assuming no increase in nominal wages (UAH 57,437 at 5\% annual wage growth, UAH 77,109 at 10\% annual wage growth). The current baby bonus is set at UAH 41,280, which is divided into a lump sum payment of UAH 10,320 immediately following childbirth and 860 per month for the next three years, which has the NPV of UAH 34,920. This is 10,000 less than the most conservative NPV of the motherhood wage penalty. Although the difference does not seem to be insurmountable, one should remember that the calculation of the cumulative motherhood wage penalty is based on the average monthly wage, while the amount of the baby bonus is fixed. Thus, the higher the wage, the larger is the difference between the cumulative motherhood wage penalty and the baby bonus, and therefore, less effective the baby bonus is in stimulating fertility among higher earners. This may explain the evidence of the disproportionate increase in fertility among poor and marginalized groups of the population. ${ }^{25}$

Looking ahead for the reforms after the Revolution of dignity, we expect an upward pressure on the motherhood wage penalty hindering any attempts to slower down population decline, which represents a clear threat to the country's long-term economic growth. First, this relates to the legal system reform which would lead to greater enforcement of existing legislation, and therefore increase the cost of maternity leave to employers. Second, the inevitable Pensions reform will increase the statutory retirement age and therefore decrease availability of alternative childcare options from grandparents. Both of these reforms will create pressure to increase the motherhood wage penalty. And, although there is no way to avoid these much needed changes, policy makers can prepare to tackle their unintended negative consequences. Based on our interpretation of the literature, this could be achieved through two channels. One is to improve the quality and availability of public childcare and/or create an attractive business environment for private initiatives in this sector. The other is to promote cultural norms supporting maternal employment through information campaigns.

\footnotetext{
${ }^{24} \mathrm{http}$ //www.calculatorsoup.com/calculators/financial/present-value-cash-flows-calculator.php used for calculations.

${ }^{25}$ http://www.niss.gov.ua/articles/940/.
} 


\section{References}

Abendroth, Anja-Kristin, Matt L. Huffman, and Judith Treas. (2014). The parity penalty in life course perspective motherhood and occupational status in 13 European countries. American Sociological Review, 0003122414545986.

Albrecht, James et al. (1999). Career interruptions and subsequent earnings: a re-examination using Swedish data. Journal of Human Resources: 294-311.

Amuedo-Dorantes, C. and J. Kimmel (2005). The motherhood wage gap for women in the United States : the importance of college and fertility delay. Review of Economics of the Household Vol. 3(1): 17-48.

Anderson, Debora, Melissa Binder and Kate Krause. (2002). The Motherhood Wage Penalty: Which Mothers Pay It and Why? American Economic Review. Vol. 92(2): 354-358.

Arzhenovskiy, Sergey and Darya Artamonova. (2007). Econometric Estimation of the Wage Penalty for the Motherhood. Applied Econometrics. Publishing House "SINERGIA PRESS". Vol. 7(3): 66-79.

Baum, Charles (2002). The Effect of Work Interruptions on Women's Wages. Labour, 16(1): 1-37

Becker, Gary. 1957. The Economics of Discrimination. Chicago: The University of Chicago Press, 1971.

Becker, Gary. 1965. A Theory of the Allocation of Time. The Economic Journal. Vol. 75 (299): 493-517

Becker, Gary. 1985. Human Capital, Effort, and Sexual Division of Labor. Journal of Labor Economics. University of Chicago Press. Vol. 3(1): 33-58.

Blackburn, McKinley, David Bloom and David Neumark. (1990). Fertility Timing, Wages and Human Capital. NBER Working Paper No. 3422.

Bloom, David, David Canning, and Günther Fink. (2010). Implications of population ageing for economic growth. Oxford Review of Economic Policy, Oxford University Press, vol. 26(4), pages 583-612, Winter.

Budig, Michelle and Paula England. (2001). The wage penalty for motherhood. American sociological review: 204-225.

Budig, Michelle, Joya Misra, and Irene Boeckmann. (2012). The Motherhood Penalty in Cross-National Perspective: The Importance of Work-Family Policies and Cultural Attitudes Social Politics Vol. 19 (2): 163 193

Buligescu, Bianca, et al. (2009). Panel estimates of the wage penalty for maternal leave. Oxford Economic Papers 61.suppl 1 i35-i55.

Cole, Jonathan and Harriet Zuckerman. (1987). Marriage, motherhood, and research performance in science. Scientific American. Vol. 256(2): 119-125.

Davies, Rhys and Gaelle Pierre. (2005). The family gap in pay in Europe: A cross-country study. Labour Economics 12.4 (2005): 469-486.

Drolet, Marie. (2002). New evidence on gender pay differentials: Does measurement matter? Canadian Public Policy/Analyse de Politiques: 1-16.

Dustmann, Christian and María Engracia Rochina-Barrachina. (2000). Selection Correction in Panel Data Models: An Application to Labor Supply and Wages. IZA DP No. 162. 
Einhorn, B. (1993). Cinderella goes to market. Citizenship, Gender, and Women's Movements in East Central Europe. Verso.

Felfe, Christina. (2012). The motherhood wage gap: What about job amenities? Labour Economics 19(1): 5967.

Fletcher, Jason and Barbara Wolfe. (2008). Education and Labor Market Consequences of Teenage Childbearing: Evidence Using the Timing of Pregnancy Outcomes and Community Fixed Effects. Journal of Human Resources. Vol. 44(2): 303-325.

Fox, Mary Frank. (2005). Gender, family characteristics, and publication productivity among scientists. Social Studies of Science. Vol.35: 131-150

Gangl, Markus, and Andrea Ziefle. (2009). Motherhood, Labor Force Behavior, and Women's Careers: An Empirical Assessment of the Wage Penalty for Motherhood in Britain, Germany, and the United States.Demography Vol. 46(2): 341-369.

Ganguli, Ina and Katrine Terrell. (2009). Closing Gender Wage Gaps in Ukraine: Composition, Returns and the Minimum Wage. Revise and Resubmit, Industrial \& Labor Relations Review

Ganguli, Ina and Katrine Terrell. (2005). Wage Ceilings and Floors: The Gender gap in Ukraine's Transition. IZA Discussion Paper No. 1776.

Gerry, Christopher, Byung-Leon Kim and Carmen Li. (2004). The Gender Wage Gap and Wage Arrears in Russia: Evidence from RLMS. Journal of Population Economics. Vol. 17(2): 267-288.

Gorodnichenko, Yuriy and Klara Sabirianova Peter. (2004). Returns to shooling in Russia and Ukraine: A Semiparametric Approach to Cross-Country Comparative Analysis. Journal of Comparative Economics. Vol.333: 324-350.

Gupta, Nabanita Datta and Nina Smith. (2001). Children and Career Interruptions: The Family Gap in Denmark. Economica. London School of Economics and Political Science. Vol. 69(276): 609-29.

Perelli-Harris, Brienna. (2005). The Path to Lowest-Low Fertility in Ukraine. Population Studies, Vol. 59, No. 1: pp. 55-70.

Heckman, James .J. (1979). Sample selection bias as a specification error. Econometrica. Vol. 47: 153-162.

ILO. (2014). Maternity and paternity at work: Law and practice across the world. Book. Accessed online at http://www.ilo.org/global/publications/ilo-bookstore/order-online/books/WCMS_242615/lang--en/index.htm on April 10, 2015.

Institute of Demography and Social Science (IDSS). (2009). Family and Family Relations in Ukraine: Current State and Development Trends. Kyiv. “Osnova-Print” Ltd. (in Ukrainian). Accessed online at http://www.unfpa.org.ua/files/articles/1/75/Family-ukr-WEB_copy.pdf on September 4, 2015.

Institute of Demography and Social Science (IDSS). (2013). Analytical Research on Women's Participation tn the Labour Force in Ukraine. Manuscript. Accessed online at http://www.idss.org.ua/monografii/2013 en_womens\%20participation.pdf on April 10, 2015.

Jappens, Maaike and Van Bavel, J. (2012). Regional family norms and child care by grandparents in Europe. Demographic Research,. 27(4), 85-120. 
Joshi, Heather, Pierella Paci, and Jane Waldfogel. (1999). The wages of motherhood: better or worse? Cambridge Journal of Economics 23(5): 543-564.

Kalist, David. (2008). Does Motherhood Affect Productivity, Relative Performance, and Earnings? Journal of Labor Research. Vol. 29(3): 219-235.

Kahn, J. R., J. García-Manglano, et al. (2014). The Motherhood Penalty at Midlife: Long-Term Effects of Children on Women's Careers. Journal of Marriage and Family Vol. 76(1): 56-72.

Kalleberg, Arne L. (2003). Flexible firms and labor market segmentation effects of workplace restructuring on jobs and workers. Work and Occupations 30(2): 154-175.

Kimmel, Jean and Thomas J. Kniesner. (1998). New evidence on labor supply: Employment versus hours elasticities by sex and marital status. Journal of Monetary Economics. Vol.42: 289-301.

Korenman, Sanders and David Newmark. (1990). Marriage, Motherhood and Wages. The Journal of Human Resources. Vol. 27(2): 233-255.

Kunze, Astrid and Matte Ejrnaes. (2004). Wage Dips and Drops around First Birth. IZA Discussion Paper No. 1011.

Lang, Kevin and Adam Ashcraft. (2013). The Consequences of Teenage Childbearing: Consistent Estimates When Abortion Makes Miscarriage Non-random. The Economic Journal. Vol.123 (571): 845-905.

Lisenkova, K., R. McQuaid and R. E. Wright. (2010) Demographic change and labour markets, Twenty-First Century Society: Journal of the Academy of Social Sciences, vol. 5, pp. 243-259.

Livermore, Tanya, Joan Rodgers, and Peter Siminski. (2011). The Effect of Motherhood on Wages and Wage Growth: Evidence for Australia. Economic Record 87(s1): 80-91.

Loughran, David and Zissimopoulos, Julie (2009). Why wait? The effect of marriage and childbearing on the wages of men and women. Journal of Human Resources, 44(2): 326-349.

Meurs, Dominique, Ariane Pailhé, and Sophie Ponthieux. (2010). Child-related career interruptions and the gender wage gap in France. Annals of Economics and Statistics/Annales d'Économie et de Statistique (2010): $15-46$.

Miller, A. (2011). The effects of motherhood timing on career path. Journal of Population Economics Vol. 24(3): 1071-1100.

Mincer, J. (1958). Investment in human capital and personal income distribution. The Journal of Political Economy, 281-302.

Mroz, Thomas. (1987). The Sensitivity of an Empirical Model of Married Women's Hours of Work to Economic and Statistical Assumptions. Econometrica. Vol. 55(4): 765-799.

O'Dorchai, Sile Padraigin. 2008. Pay inequality in 25 European countries. DULBEA Working Papers 08-06rs.

Phelps, Edmund. (1972). The Statistical Theory of Racism and Sexism. American Economic Review 62 (4): 659-661.

Phipps, S., Burton, P. and Lethbridge, L. (2001). In and out of the labor market: long-term income consequences of child-related interruptions to women's paid work. Canadian Journal of Economics, vol. 34, no. 2, 411-29. 
Rochina-Barrachina, María Engracia. (1999). A new estimator for panel data sample selection models. Annals of Economics and Statistics. No. 55/56: 153-181.

Ruhm, C. (1998). The Economic Consequences of Parental Leave Mandates: Lessons from Europe. The Quarterly Journal of Economics, Vol. 113(1): 285-317

Safarova, Gaiane, Sergei Scherbov, and Sergei Pirozhkov. (2008). "Future trends of population ageing in Russia and Ukraine: a probabilistic view” European Population Conference. Barcelona, Spain.

Sigle-Rushton, Wendy and Jane Waldfogel. (2007). Motherhood and women's earnings in Anglo-American, Continental European, and Nordic Countries. Feminist Economics. Vol. 13(2):55-91.

Simonsen, Marianne, and Lars Skipper. (2006). The costs of motherhood: an analysis using matching estimators. Journal of Applied Econometrics, 21(7), 919-934.

Simonsen, Marianne, and Lars Skipper. (2012). The family gap in wages: What wombmates reveal. Labour Economics, 19(1), 102-112.

Sologoub, Ilona. (2013). Fertility Determinants in Ukraine. EERC Working Paper Series 13/13 ${ }^{\mathrm{e}}$. EERC Research Network, Russia and CIS.

Taniguchi, Hiromi. (1999). The timing of Childbearing and Women's wages. Journal of Marriage and Family. Vol. 61: 1008-1019.

Verbeek, Marno. (2008). A Guide to Modern Econometrics. John Wiley \& Sons, LTD.

Viitanen, Tarja. (2004). The Impact of Children on Female Earnings in Britain. Discussion Paper. DIW Berlin and University of Warwick.

Viitanen, Tarja (2014). "The motherhood wage gap in the UK over the life cycle." Review of Economics of the Household Vol. 12(2): 259-276.

Waldfogel, Jane. (1995) The price of motherhood: family status and women's pay in young British cohort. Oxford Economic Papers (1995): 584-610.

Waldfogel, Jane. (1997). The Effect of Children on women's wages. American Sociological Review. Vol. 62(2): 209-217.

Waldfogel, Jane. (1998). Family gap for Young women in United States and Britain: Can Maternity leave make a difference? Journal of Labor Economics. Vol. 16(3): 505- 545.

Wooldridge, Jeffrey M. (1995) Selection corrections for panel data models under conditional mean independence assumptions. Journal of Econometrics. Vol.68: 115- 132.

Wooldridge, Jeffrey M. (2002). Econometric Analysis of Cross Sectional and Panel Data. The MIT Press. Cambridge. Massachusetts. 


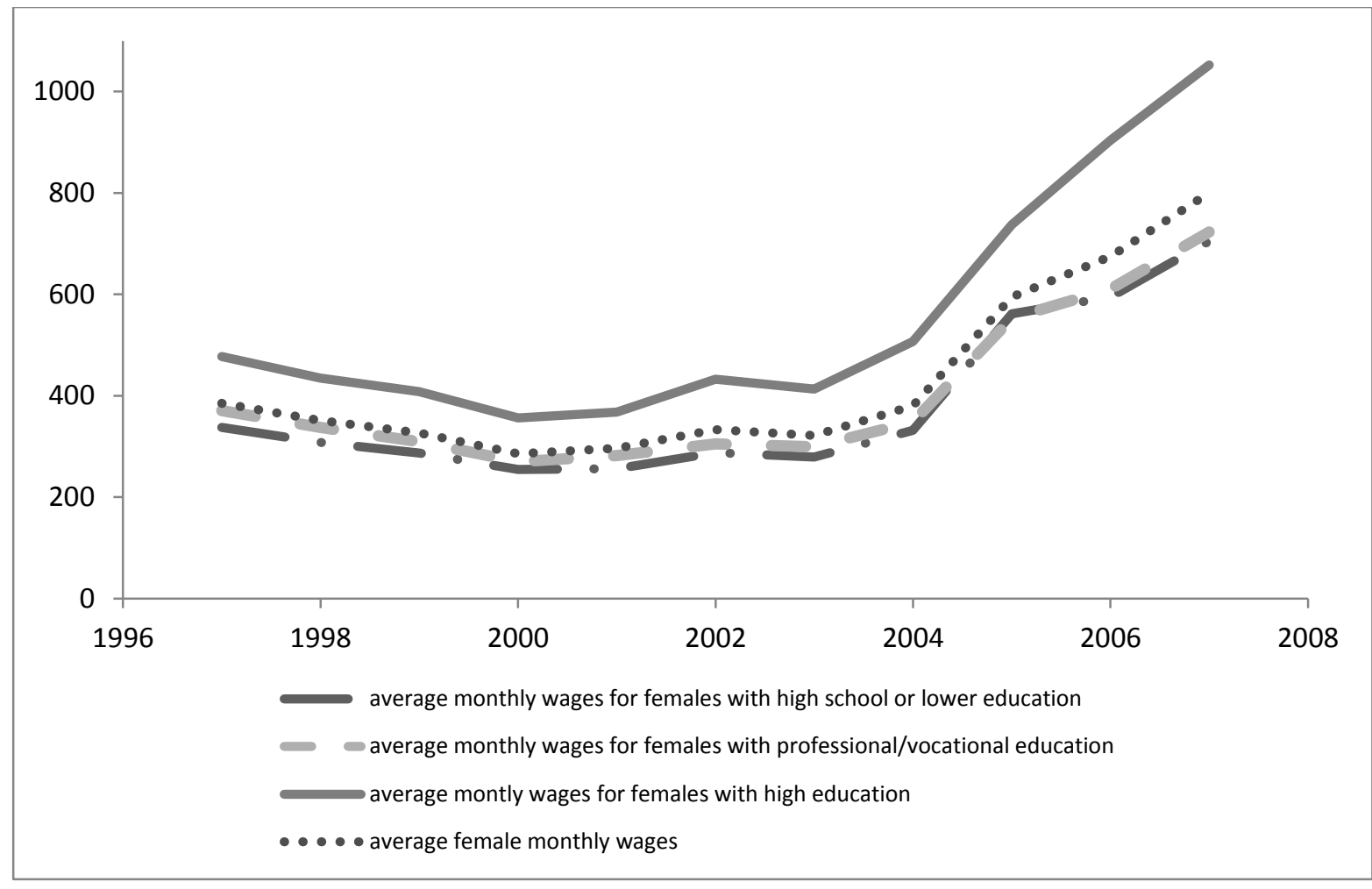

Figure 1: Average wage of females in the regression sample.

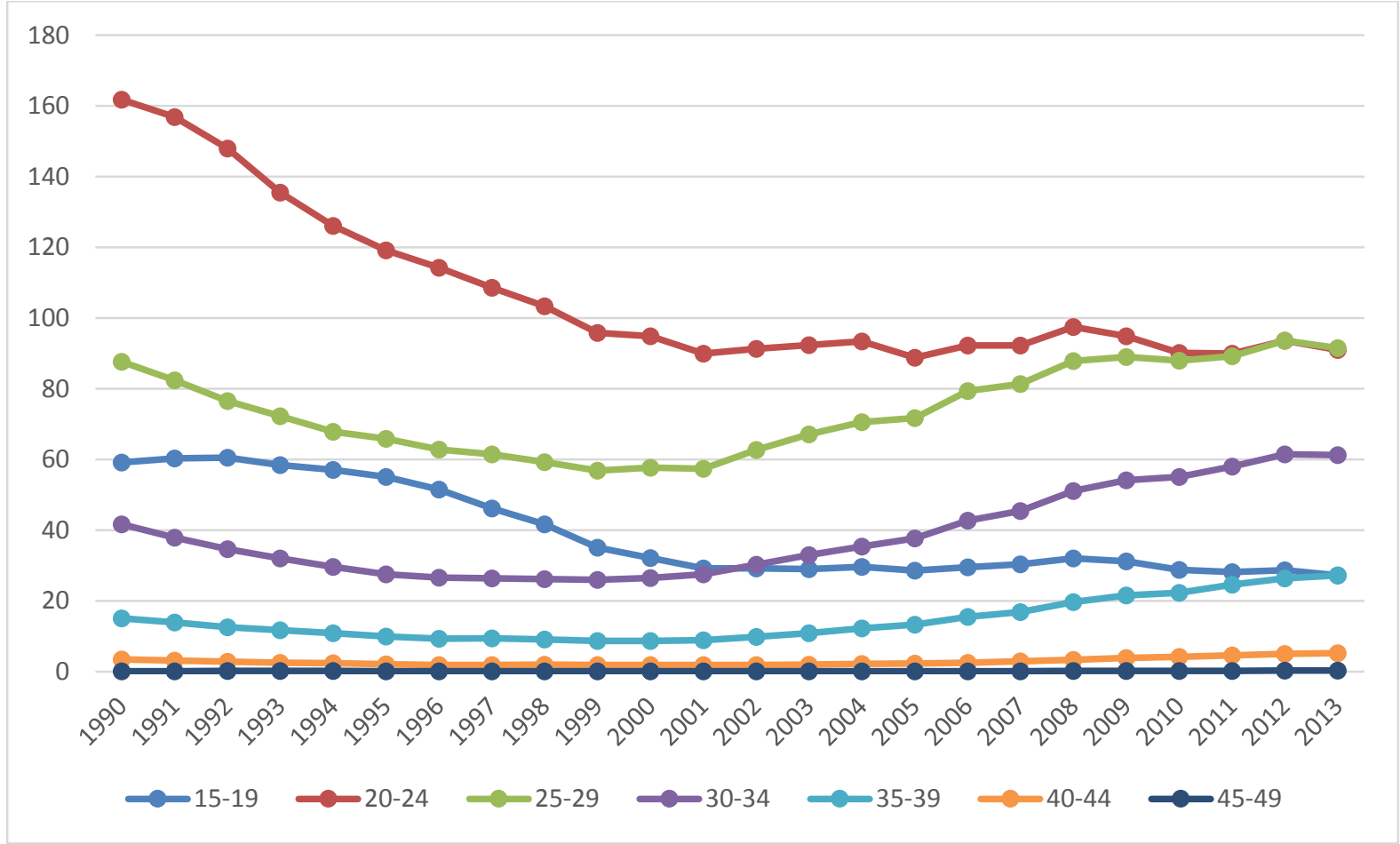

Figure 2: Birth rate coefficients in Ukraine by age of mothers (number of newborns per 1000 of females of correspondent age ${ }^{26}$ ) in 1990-2013 Source: State Statistical Committee (http://www.ukrstat.gov.ua)

${ }^{26}$ Number of newborns from mothers younger than 15 and older than 49 are included into these groups. 


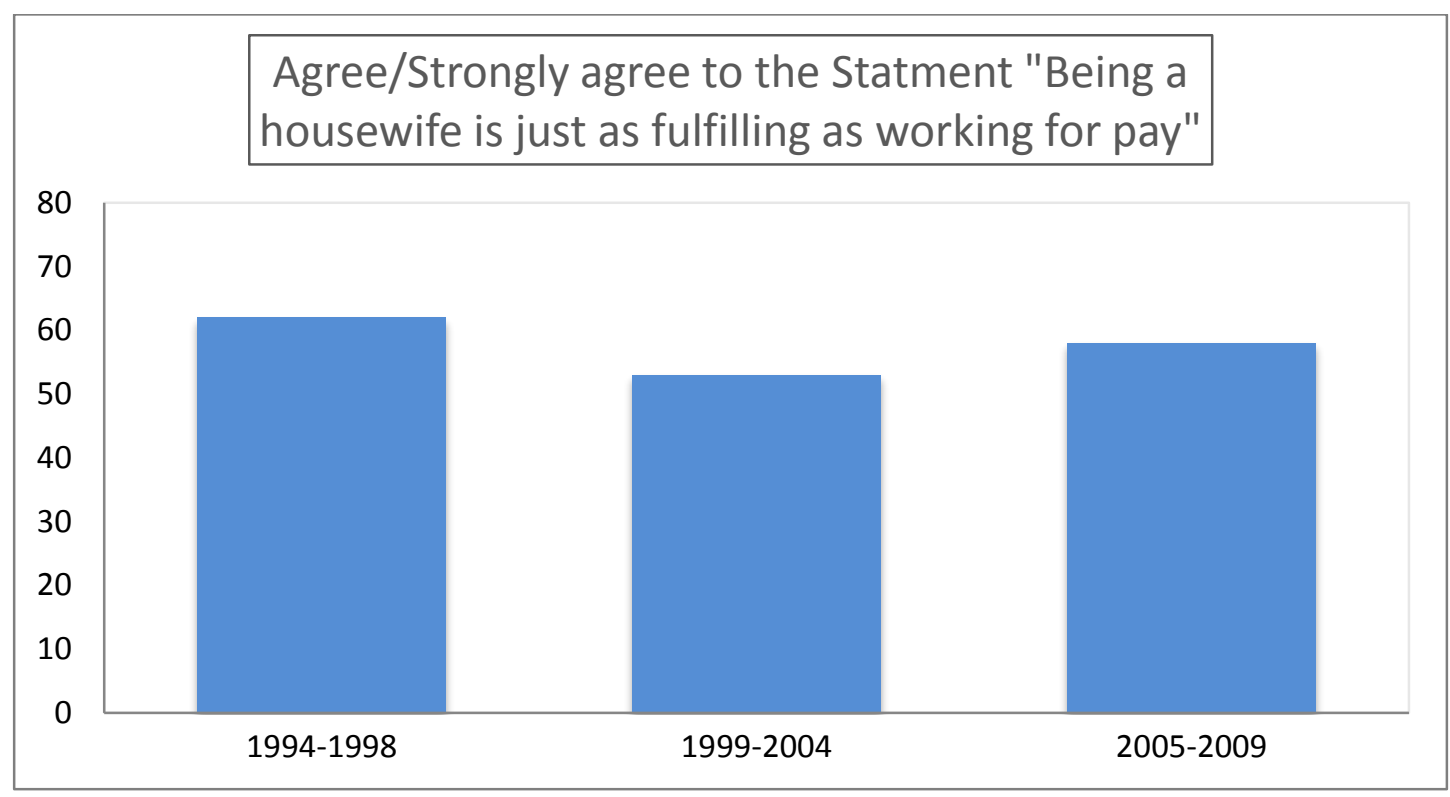

Figure 3: Comparison of attitudes toward maternal employment in Ukraine based on agreement with the statement "Being a housewife is just as fulfilling as working for pay" from the World Values Survey Waves 3, 4 and 5.

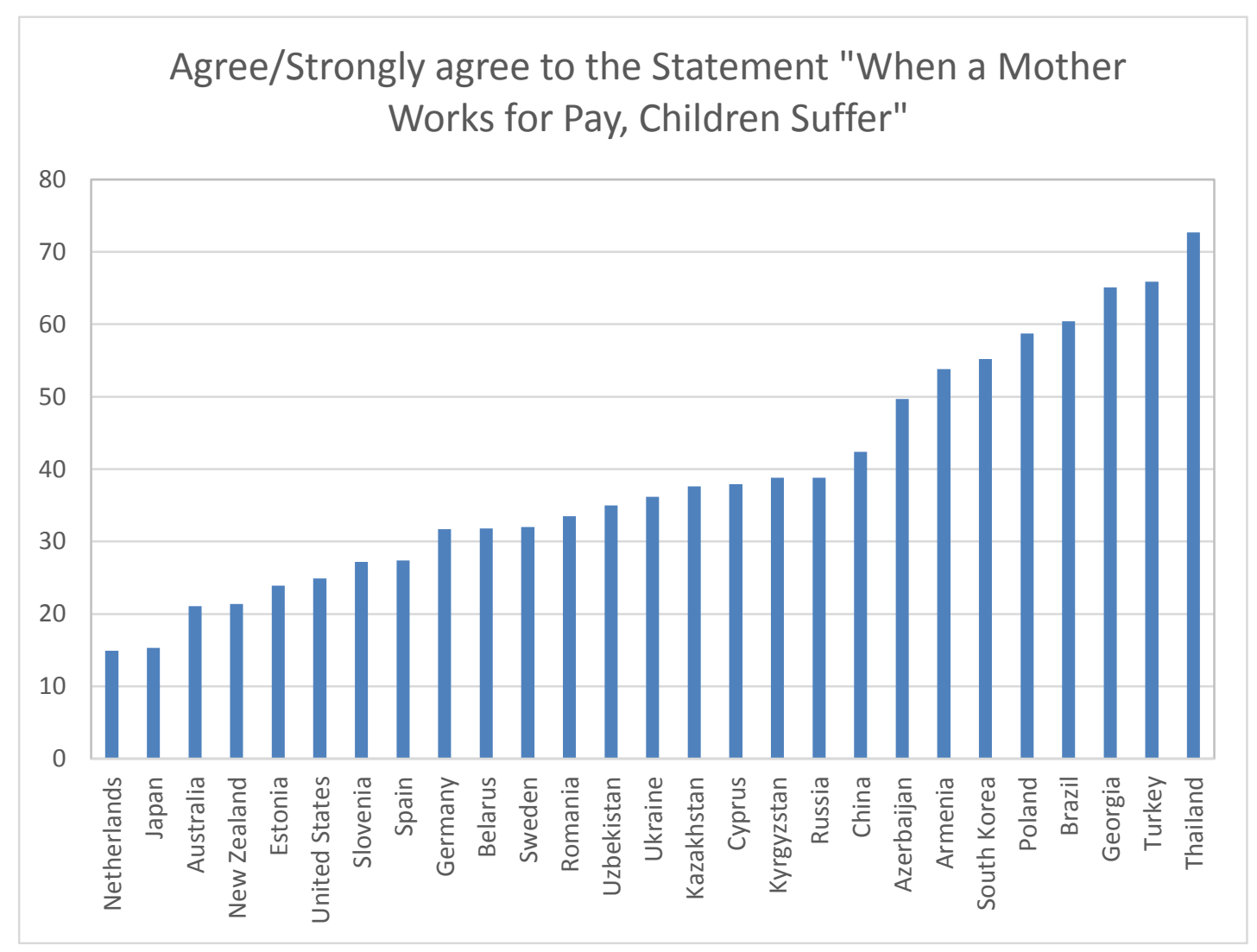

Figure 4: Comparison of attitudes toward maternal employment in different countries based on agreement with the statement "When a Mother Works for Pay, Children Suffer" from the World Values Survey Wave 6: 2010-2014. 
Table 1: Selected results on the wage penalty of motherhood from the previous literature

\begin{tabular}{|c|c|c|c|}
\hline Study & Data set & Methods & Results \\
\hline Budig, M.J. and & 1982-1993 & FE and OLS & The wage penalty $7 \%$ per child $(5 \%$ \\
\hline England, P. (2001) & NLSY & & controlling for work experience) \\
\hline Datta Gupta and & $1980-95$ & $\mathrm{FE}$ & Temporary 6-7\% negative effects. \\
\hline Smith (2001) & $\begin{array}{l}\text { Danish panel } \\
\text { data }\end{array}$ & selectivity & $\begin{array}{l}\text { The effect disappears by the age of } \\
40\end{array}$ \\
\hline Hill, M.S. (1979) & 1976 PSID & OLS & The wage penalty $6-7 \%$ per child. \\
\hline $\begin{array}{l}\text { Korenman, S. and } \\
\text { Neumark, D. (1990) }\end{array}$ & 1982 NLS-YW & $\begin{array}{l}\text { OLS, FD, FE } \\
\text { and IV }\end{array}$ & $\begin{array}{l}\text { The wage penalty } 7 \% \text { for one child } \\
\text { and } 22 \% \text { for two or more children }\end{array}$ \\
\hline $\begin{array}{l}\text { Kunze, } A \text { and Ejrnaes } \\
\text { (2004) }\end{array}$ & $\begin{array}{l}\text { 1975-1997 } \\
\text { IABS, West } \\
\text { Germany }\end{array}$ & OLS and IV & $\begin{array}{l}10-20 \% \text { drop in wages after first } \\
\text { birth. }\end{array}$ \\
\hline Viitanen, T (2004) & NCDS of UK & $\begin{array}{l}\text { OLS, double } \\
\text { selection }\end{array}$ & $\begin{array}{l}\text { The } 19 \%-22 \% \text { wage penalty, } 10 \%- \\
13 \% \text { obtained from double selection } \\
\text { model. }\end{array}$ \\
\hline Waldfogel, J. (1995) & NCDS & $\begin{array}{l}\text { OLS, FD and } \\
\text { FE }\end{array}$ & $\begin{array}{l}\text { The average wage penalty for } \\
\text { motherhood } 22 \%\end{array}$ \\
\hline Waldfogel, J. (1997) & $\begin{array}{l}\text { 1968- } 1988 \\
\text { NLS-YW }\end{array}$ & $\begin{array}{l}\text { OLS, FD and } \\
\text { FE }\end{array}$ & $\begin{array}{l}\text { The wage penalty } 4 \% \text { for one child } \\
\text { and } 12 \% \text { for two or more children. }\end{array}$ \\
\hline $\begin{array}{l}\text { Waldfogel, J. } \\
\text { (1998a) }\end{array}$ & $\begin{array}{l}1980 \text { NLS- } \\
\text { YW and } \\
1991 \text { NLSY }\end{array}$ & OLS & $\begin{array}{l}\text { The wage penalty at age } 3017 \% \text { in } \\
1980 \text { and } 25 \% \text { in } 1991\end{array}$ \\
\hline $\begin{array}{l}\text { Waldfogel, J. } \\
\text { (1998b) }\end{array}$ & $\begin{array}{l}\text { NLSY and } \\
\text { NCDS }\end{array}$ & $\begin{array}{l}\text { OLS, FD and } \\
\text { FE }\end{array}$ & $\begin{array}{l}\text { The wage penalty } 20 \% \text { for US at age } \\
30 \text { and } 20 \% \text { for UK at age } 33\end{array}$ \\
\hline $\begin{array}{l}\text { Almuendo-Dorates, } \\
\text { and Kimmel, (2005). }\end{array}$ & NLSY 79 & OLS, FE & $\begin{array}{l}\text { The wage penalty is } 6,3 \% \text { for one } \\
\text { child and } 12,5 \% \text { for two or more }\end{array}$ \\
\hline
\end{tabular}




\begin{tabular}{|c|c|c|c|c|c|c|}
\hline \multirow[t]{2}{*}{ Variable $(\%)$} & \multicolumn{2}{|c|}{1997} & \multicolumn{2}{|c|}{2007} & \multicolumn{2}{|c|}{$\begin{array}{c}\text { Pooled } \\
\text { 1997-2007 }\end{array}$} \\
\hline & all & $\begin{array}{c}\text { employed } \\
\text { (2) }\end{array}$ & all & $\begin{array}{l}\text { employed } \\
\text { (4) }\end{array}$ & $\begin{array}{l}\text { all } \\
(5)\end{array}$ & $\begin{array}{c}\text { employed } \\
\text { (6) }\end{array}$ \\
\hline Age $<25$ & 15,31 & 4,07 & 16,74 & 8,74 & 17,27 & 6,97 \\
\hline $25-35$ & 18,08 & 17,9 & 17,96 & 19,77 & 17,83 & 18,8 \\
\hline $35-45$ & 21,37 & 28,11 & 19,34 & 28,11 & 19,77 & 28,08 \\
\hline $45-55$ & 23,12 & 33,14 & 23,89 & 29,62 & 23,86 & 32,32 \\
\hline $55-65$ & 22,12 & 16,79 & 22,07 & 13,76 & 21,26 & 13,83 \\
\hline \multicolumn{7}{|l|}{ Children } \\
\hline none & 47,51 & 33,14 & 47,24 & 40,25 & 46,56 & 33,38 \\
\hline one & 32,69 & 42,23 & 33,93 & 38,29 & 32,92 & 40,55 \\
\hline two & 17,4 & 21,97 & 16,45 & 19,5 & 17,92 & 23,44 \\
\hline $\begin{array}{l}\text { more than } \\
\text { two }\end{array}$ & 2,4 & 2,66 & 2,37 & 1,96 & 2,6 & 2,63 \\
\hline \multicolumn{7}{|l|}{ Education } \\
\hline _high schoo ${ }^{[1]}$ & 44,51 & 28,25 & 33,03 & 19,83 & 40,44 & 24,59 \\
\hline vocational & 41,85 & 51,48 & 49,78 & 55,71 & 44,88 & 53,04 \\
\hline university & 13,64 & 20,27 & 17,19 & 24,46 & 14,68 & 22,37 \\
\hline Married & 57,5 & 69,01 & 63,34 & 65,82 & 57,7 & 66,29 \\
\hline Employed & 56,74 & 100 & 55,23 & 100 & 53,47 & 100 \\
\hline Wage(monthly) & & $\begin{array}{c}383,10 \\
(234.56)\end{array}$ & & $\begin{array}{c}800,27 \\
(669.96)\end{array}$ & & $\begin{array}{c}428,20 \\
(399.31)\end{array}$ \\
\hline Wage (hourly) & & & & & & $\begin{array}{c}2.54 \\
(2.36) \\
\end{array}$ \\
\hline $\mathrm{N}$ & 3833 & 1352 & 3118 & 1533 & 39563 & 15656 \\
\hline
\end{tabular}

Note: A reduction in the sample size when going from full sample to the analytic sample (called "employed") is due to restrictions on working age, work status, and wage information available. Standard errors are in parenthesis, presented for continuous variables only. 
Table 3: Descriptive statistics female sub - sample of ULMS data set (Pooled)

\begin{tabular}{|c|c|c|c|c|c|c|}
\hline \multirow{2}{*}{ VARIABLES } & \multicolumn{2}{|c|}{ all females } & \multicolumn{2}{|c|}{ mothers } & \multicolumn{2}{|c|}{ not mothers } \\
\hline & all & employed & all & employed & all & $\begin{array}{c}\text { employed } \\
\text { (6) }\end{array}$ \\
\hline \multirow[t]{2}{*}{ Current mother (\%) } & 53.44 & 66.62 & 100.00 & 100.00 & & \\
\hline & 0.77 & 0.96 & 1.45 & 1.44 & & \\
\hline \multirow[t]{2}{*}{ Number of kids $(0-18)$} & $(0.86)$ & $(0.84)$ & $(0.63)$ & $(0.60)$ & & \\
\hline & 0.14 & 0.12 & 0.25 & 0.17 & & \\
\hline \multirow[t]{2}{*}{ Number of kids $(0-6)$} & $(0.39)$ & $(0.35)$ & $(0.50)$ & $(0.41)$ & & \\
\hline & 0.64 & 0.84 & 1.19 & 1.26 & & \\
\hline Number of kids (7-18) & $(0.81)$ & $(0.83)$ & $(0.75)$ & $(0.70)$ & & \\
\hline No children (\%) & 46.56 & 33.38 & 0.00 & 0.00 & 1.00 & 1.00 \\
\hline One child (\%) & 32.92 & 40.55 & 61.61 & 60.87 & & \\
\hline Two or more children (\%) & 20.52 & 26.07 & 38.39 & 39.13 & & \\
\hline \multirow[t]{2}{*}{ Age at first birth } & $\begin{array}{l}22.45 \\
(3.66)\end{array}$ & $\begin{array}{l}22.61 \\
(3.78)\end{array}$ & $\begin{array}{l}22.51 \\
(3.78)\end{array}$ & $\begin{array}{l}22.66 \\
(3.87)\end{array}$ & $\begin{array}{l}22.33 \\
(3.35)\end{array}$ & $\begin{array}{l}22.42 \\
(3.46)\end{array}$ \\
\hline & $\begin{array}{c}41.93 \\
(14.24)\end{array}$ & $\begin{array}{c}43.24 \\
(11.06)\end{array}$ & $\begin{array}{c}44.49 \\
(10.89)\end{array}$ & $\begin{array}{l}44.25 \\
(9.34)\end{array}$ & $\begin{array}{c}38.99 \\
(16.83)\end{array}$ & $\begin{array}{c}41.22 \\
(13.66)\end{array}$ \\
\hline High school (\%) & 40.44 & 24.59 & 30.20 & 23.55 & 52.20 & 26.67 \\
\hline Professional/Vocational (\%) & 44.88 & 53.04 & 52.36 & 54.04 & 36.28 & 51.05 \\
\hline University (\%) & 14.68 & 22.37 & 17.43 & 22.42 & 11.52 & 22.27 \\
\hline Married (\%) & 57.70 & 66.29 & 74.92 & 74.86 & 37.94 & 49.18 \\
\hline Never married (\%) & 14.19 & 9.40 & 2.67 & 2.45 & 27.41 & 23.27 \\
\hline Employed (\%) & 53.47 & 100.00 & 65.97 & 100.00 & 39.12 & 100.00 \\
\hline \multirow[t]{2}{*}{ Experience (years) } & $\begin{array}{c}16.56 \\
(13.70)\end{array}$ & $\begin{array}{c}19.50 \\
(11.48)\end{array}$ & $\begin{array}{c}18.44 \\
(11.65)\end{array}$ & $\begin{array}{c}20.06 \\
(10.11)\end{array}$ & $\begin{array}{c}14.40 \\
(15.45)\end{array}$ & $\begin{array}{c}18.37 \\
(13.75)\end{array}$ \\
\hline & & 38.78 & & 38.63 & & 39.07 \\
\hline \multirow{2}{*}{ Hours worked per week } & & $(5.88)$ & & (6.18) & & (5.21) \\
\hline & & 428.20 & & 412.04 & & 460.47 \\
\hline Wage (monthly) & & (399.31) & & $(369.93)$ & & $(450.57)$ \\
\hline Wage (hourly) & & $\begin{array}{c}2.54 \\
(2.36)\end{array}$ & & $\begin{array}{c}2.45 \\
(2.22)\end{array}$ & & $\begin{array}{c}2.70 \\
(2.62)\end{array}$ \\
\hline \# Observations & 39563 & 15656 & 21142 & 10430 & 18421 & 5226 \\
\hline
\end{tabular}

Note: A reduction in the sample size when going from full sample to the analytic sample (called "employed") is due to restrictions on working age, work status, and wage information available. Standard errors are in parenthesis, presented for continuous variables only. 
Table 4: Results of estimation of log-wage regression. ULMS 1997-2007.

\begin{tabular}{|c|c|c|c|c|c|}
\hline $\begin{array}{l}\text { Logarithm of hourly } \\
\text { wage }\end{array}$ & $\begin{array}{c}\text { Pooled } \\
\text { OLS } \\
\text { (1) }\end{array}$ & $\begin{array}{c}\text { OLS } \\
\text { selection } \\
(2)\end{array}$ & $\begin{array}{l}\text { FE } \\
(3) \\
\end{array}$ & $\begin{array}{c}\text { FE } \\
\text { selection } \\
(4)\end{array}$ & $\begin{array}{c}\text { FE } \\
\text { selection } \\
(5)\end{array}$ \\
\hline One child & $\begin{array}{c}-0.0775^{* *} \\
(0.0233)\end{array}$ & $\begin{array}{c}-0.0775^{* *} \\
(0.0258)\end{array}$ & $\begin{array}{c}-0.1635^{* *} \\
(0.0259)\end{array}$ & $\begin{array}{c}-0.1693^{* *} \\
(0.0263)\end{array}$ & $\begin{array}{c}-0.1647^{* *} \\
(0.0271)\end{array}$ \\
\hline Two or more children & $\begin{array}{c}-0.1173 * * \\
(0.0264)\end{array}$ & $\begin{array}{c}-0.1173 * * \\
(0.0273)\end{array}$ & $\begin{array}{c}-0.2743^{* *} \\
(0.0382)\end{array}$ & $\begin{array}{c}-0.2913^{* *} \\
(0.0395)\end{array}$ & $\begin{array}{c}-0.2760 * * \\
(0.0398)\end{array}$ \\
\hline Age & $\begin{array}{c}0.0140 \\
(0.0072)\end{array}$ & $\begin{array}{c}0.0140 \\
(0.0122)\end{array}$ & $\begin{array}{c}0.0421 * * \\
(0.0076)\end{array}$ & $\begin{array}{c}0.0540^{* *} \\
(0.0084)\end{array}$ & $\begin{array}{c}0.0548 * * \\
(0.0088)\end{array}$ \\
\hline Age squared & $\begin{array}{c}-0.0002^{* *} \\
(0.0001)\end{array}$ & $\begin{array}{l}-0.0002 \\
(0.0002)\end{array}$ & $\begin{array}{c}-0.0004^{* *} \\
(0.0001)\end{array}$ & $\begin{array}{c}-0.0005^{* *} \\
(0.0001)\end{array}$ & $\begin{array}{c}-0.0005^{* *} \\
(0.0001)\end{array}$ \\
\hline $\begin{array}{l}\text { Vocational/professional } \\
\text { education }\end{array}$ & $\begin{array}{l}0.0984 * * \\
(0.0235)\end{array}$ & $\begin{array}{c}0.0982^{* *} \\
(0.0346)\end{array}$ & $\begin{array}{l}0.1161 * \\
(0.0533)\end{array}$ & $\begin{array}{c}0.1911^{* *} \\
(0.0580)\end{array}$ & $\begin{array}{c}0.1745^{* *} \\
(0.0592)\end{array}$ \\
\hline High education & $\begin{array}{l}0.3986 * * \\
(0.0293)\end{array}$ & $\begin{array}{c}0.3984^{* *} \\
(0.0534)\end{array}$ & $\begin{array}{c}0.3143^{* *} \\
(0.0660)\end{array}$ & $\begin{array}{c}0.3987^{* *} \\
(0.0727)\end{array}$ & $\begin{array}{c}0.3631 * * \\
(0.0721)\end{array}$ \\
\hline Experience & $\begin{array}{l}0.0076^{*} \\
(0.0037)\end{array}$ & $\begin{array}{c}0.0075 \\
(0.0084)\end{array}$ & $\begin{array}{c}0.1071^{* *} \\
(0.0056)\end{array}$ & $\begin{array}{c}0.1226 * * \\
(0.0081)\end{array}$ & $\begin{array}{c}0.1243^{* *} \\
(0.0084)\end{array}$ \\
\hline Experience squared & $\begin{array}{c}-0.0001 \\
(0.0001)\end{array}$ & $\begin{array}{l}-0.0001 \\
(0.0001)\end{array}$ & $\begin{array}{c}-0.0008^{* *} \\
(0.0001)\end{array}$ & $\begin{array}{c}-0.0012^{* *} \\
(0.0002)\end{array}$ & $\begin{array}{c}-0.0013^{* *} \\
(0.0002)\end{array}$ \\
\hline Never Married & $\begin{array}{c}0.1072 * * \\
(0.0387)\end{array}$ & $\begin{array}{c}0.1072 * * \\
(0.0387)\end{array}$ & $\begin{array}{l}-0.0371 \\
(0.0498)\end{array}$ & $\begin{array}{l}-0.0405 \\
(0.0498)\end{array}$ & $\begin{array}{l}-0.0027 \\
(0.0475)\end{array}$ \\
\hline Married & $\begin{array}{c}0.0268 \\
(0.0214)\end{array}$ & $\begin{array}{c}0.0268 \\
(0.0216)\end{array}$ & $\begin{array}{c}0.0435 \\
(0.0268)\end{array}$ & $\begin{array}{c}0.0421 \\
(0.0268)\end{array}$ & $\begin{array}{c}0.0436 \\
(0.0268)\end{array}$ \\
\hline Part-time work & & & & & $\begin{array}{l}-0.2188 \\
(0.1139)\end{array}$ \\
\hline State/public/collective & & & & & $\begin{array}{c}-0.1192 * * \\
(0.0398)\end{array}$ \\
\hline Large (>=500 employees) & & & & & $\begin{array}{c}0.0651 \\
(0.0528)\end{array}$ \\
\hline Small (<50 employees) & & & & & $\begin{array}{l}-0.0660 \\
(0.0354)\end{array}$ \\
\hline $\begin{array}{l}\text { Share of experience in } \\
\text { large firm }\end{array}$ & & & & & $\begin{array}{c}0.0014 \\
(0.0021)\end{array}$ \\
\hline MIII's ratio & & $\begin{array}{l}-0.0006 \\
(0.1145) \\
\end{array}$ & & $\begin{array}{c}0.1098 * * \\
(0.0358) \\
\end{array}$ & $\begin{array}{c}0.1282 * * \\
(0.0371) \\
\end{array}$ \\
\hline Observations & 15,656 & 15,656 & 15,656 & 15,656 & 14,849 \\
\hline Adjusted R-squared & 0.059 & 0.059 & $0.677 \ddagger$ & $0.606 \ddagger$ & $0.690 \ddagger$ \\
\hline Number of id & & & 2,856 & 2,856 & 2,722 \\
\hline
\end{tabular}

Note: $\ddagger$ indicates instances when R-squared has been taken from the areg command in Stata. Individually clustered standard errors in parentheses $(* * * p<0.01, * * p<0.05, * p<0.1)$. 
Table 5: Fixed effect estimates for wage penalties for different model specifications.

\begin{tabular}{|c|c|c|c|c|}
\hline & $(1)$ & $(2)$ & $(3)$ & $(4)$ \\
\hline \multicolumn{5}{|l|}{ Panel A: Main Specification } \\
\hline Ever mother & $\begin{array}{c}-0.1851^{* *} \\
(0.0262)\end{array}$ & & & \\
\hline Number of children & & $\begin{array}{c}-0.1514^{* *} \\
(0.0192)\end{array}$ & & \\
\hline One child & & & $\begin{array}{c}-0.1693 * * \\
(0.0263)\end{array}$ & \\
\hline Two or more children & & & $\begin{array}{c}-0.2913^{* *} \\
(0.0395)\end{array}$ & \\
\hline Number of children (0-6) & & & & $\begin{array}{c}-0.0886 * * \\
(0.0264)\end{array}$ \\
\hline Number of children (7-18) & & & & $\begin{array}{c}-0.1676 * * \\
(0.0198) \\
\end{array}$ \\
\hline \multicolumn{5}{|c|}{ Panel B: Alternative Specification - controlling for having children older than 18} \\
\hline Ever mother & $\begin{array}{c}-0.1941^{* *} \\
(0.0285)\end{array}$ & & & \\
\hline Number of children & & $\begin{array}{c}-0.1577^{* *} \\
(0.0203)\end{array}$ & & \\
\hline One child & & & $\begin{array}{c}-0.1801^{* *} \\
(0.0286)\end{array}$ & \\
\hline Two or more children & & & $\begin{array}{c}-0.3044^{* *} \\
(0.0415)\end{array}$ & \\
\hline Number of children (0-6) & & & & $\begin{array}{c}-0.0945^{* *} \\
(0.0270)\end{array}$ \\
\hline Number of children (7-18) & & & & $\begin{array}{c}-0.1754^{* *} \\
(0.0209)\end{array}$ \\
\hline Children older than 18 & $\begin{array}{c}0.0224 \\
(0.0212)\end{array}$ & $\begin{array}{c}0.0254 \\
(0.0207)\end{array}$ & $\begin{array}{c}0.0276 \\
(0.0213)\end{array}$ & $\begin{array}{c}0.0296 \\
(0.0207)\end{array}$ \\
\hline
\end{tabular}

Panel C: Main Specification - sample of women of childbearing age

$\begin{array}{lc}\text { Ever mother } & -0.1038^{* *} \\ & (0.0313)]\end{array}$

Number of children

One child

Two or more children

Number of children (0-6 years

old)

Number of children (7-18years 
Table 6: Fixed effect estimates of the wage penalty for motherhood by education level and timing of the first birth. ULMS 1997-2004

\begin{tabular}{|c|c|c|c|c|c|c|c|c|}
\hline & \multicolumn{2}{|c|}{ All } & \multicolumn{2}{|c|}{ High school or Lower } & \multicolumn{2}{|c|}{$\begin{array}{l}\text { Vocational/ } \\
\text { Professional }\end{array}$} & \multicolumn{2}{|c|}{$\begin{array}{c}\text { Bachelor Degree or } \\
\text { Higher }\end{array}$} \\
\hline & (1) & (2) & (3) & (4) & (5) & (6) & $(7)$ & (8) \\
\hline Number of kids & $\begin{array}{c}-0.1514^{* *} \\
(0.0192)\end{array}$ & & $\begin{array}{c}-0.1778 * * \\
(0.0390)\end{array}$ & & $\begin{array}{c}-0.1731^{* *} \\
(0.0261)\end{array}$ & & $\begin{array}{c}-0.1100 * * \\
(0.0411)\end{array}$ & \\
\hline $\begin{array}{l}\text { (Number of kids) } * \text { (age at } \\
\left.1^{\text {st }} \text { birth }<20\right)\end{array}$ & & $\begin{array}{c}-0.1498 * * \\
(0.0342)\end{array}$ & & $\begin{array}{c}-0.1903 * * \\
(0.0510)\end{array}$ & & $\begin{array}{c}-0.1191 * * \\
(0.0421)\end{array}$ & & $\begin{array}{l}-0.1786 \\
(0.0966)\end{array}$ \\
\hline $\begin{array}{l}\text { (Number of kids) } *(20 \leq \\
\left.\text { age at } 1^{\text {st }} \text { birth }<25\right)\end{array}$ & & $\begin{array}{c}-0.1488 * * \\
(0.0269)\end{array}$ & & $\begin{array}{l}-0.1107^{*} \\
(0.0510)\end{array}$ & & $\begin{array}{c}-0.1623 * * \\
(0.0331)\end{array}$ & & $\begin{array}{c}-0.1506 * * \\
(0.0537)\end{array}$ \\
\hline (Number of kids) $*(25 \leq$ & & $-0.1111 * *$ & & -0.0374 & & $-0.1038^{*}$ & & $-0.1361^{*}$ \\
\hline age at $1^{\text {st }}$ birth $<30$ ) & & $(0.0343)$ & & $(0.0643)$ & & $(0.0470)$ & & $(0.0541)$ \\
\hline (Number of kids) $*$ ( age & & $-0.2261 * *$ & & $-0.4022 * *$ & & $-0.2795^{*}$ & & $-0.1622^{*}$ \\
\hline at $1^{\text {st }}$ birth $\geq 30$ ) & & $(0.0685)$ & & $(0.1237)$ & & $(0.1247)$ & & (0.0701) \\
\hline Observations & 15,656 & 15,656 & 3,850 & 3,850 & 8,304 & 8,304 & 3,502 & 3,502 \\
\hline Number of id & 2,856 & 2,856 & 850 & 850 & 1,578 & 1,578 & 606 & 606 \\
\hline
\end{tabular}

Notes: Standard errors in parentheses $(* * * p<0.01, * * p<0.05, * p<0.1)$. Numbers in parenthesis are clustered standard errors. All regressions are from the fixed effect estimation with selection and include controls as in Table 4. Results in columns (4), (6), and (8) are drawn from the same regression with interactions. Grey background of the cell in the table implies that the estimate is different from the ones for the lowest educational group at least at $10 \%$ level of significance (within the row). Estimates in bold indicate that they are statistically different from the estimate for the number of kids when the age at first birth is less than 20 within the same educational group (within the column). In Column (2),

none of the coefficients are significantly different from each other, with the exception of the effect of number of kids at the age at $1^{\text {st }}$ birth $\geq 30$ when compared to that at $(25 \leq$ age at 1st birth $<30$ ), which is marginally significant. In Column 4 , not only the coefficients in bold are statistically different from the effect of the number of kids at the youngest age at $1^{\text {st }}$ birth category, they are also different in a statistically significant way (at $5 \%$ or lower) from the second category $(20 \leq$ age at 1 st birth $<25$ ) and between each other. 
(c) 2016. This manuscript version is made available under the CC-BY-NC-ND 4.0 license http://creativecommons.org/licenses/by-nc-nd/4.0/

\section{Appendix}

Table A1: The amount of Baby bonus in Ukraine, USD

\begin{tabular}{|c|c|c|c|c|c|c|}
\hline \multirow[b]{2}{*}{ Year } & \multicolumn{6}{|c|}{ Size of the payment } \\
\hline & & $1^{\text {st }}$ Child & & 2nd Child & & 3rd Child \\
\hline 2001 & & 32 & & 32 & & 32 \\
\hline 2002 & & 38 & & 38 & & 38 \\
\hline 2003 & & 60 & & 60 & & 60 \\
\hline 2004 & & 127 & & 127 & & 127 \\
\hline 2005 & & 287 & & 287 & & 287 \\
\hline 2006 & & 1574 & & 1574 & & 1574 \\
\hline & Full amount & 1st payment & Full amount & 1st payment & Full amount & $\begin{array}{c}1 s t \\
\text { payment }\end{array}$ \\
\hline 2008 & 2423 & 950 & 4950 & 958 & 9901 & 990 \\
\hline 2011 & 2469 & 1010 & 5049 & 1010 & 10098 & 1010 \\
\hline 2012 & 3829 & 1276 & 7659 & 1276 & 15317 & 1276 \\
\hline 2013 & 4172 & 1391 & 8344 & 1391 & 16688 & 1391 \\
\hline 2014 & 1720 & 430 & 1720 & 430 & 1720 & 430 \\
\hline
\end{tabular}

all women

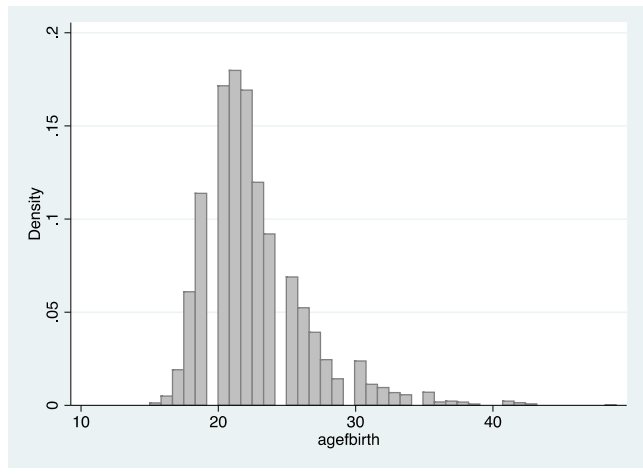

women with vocational/professional education

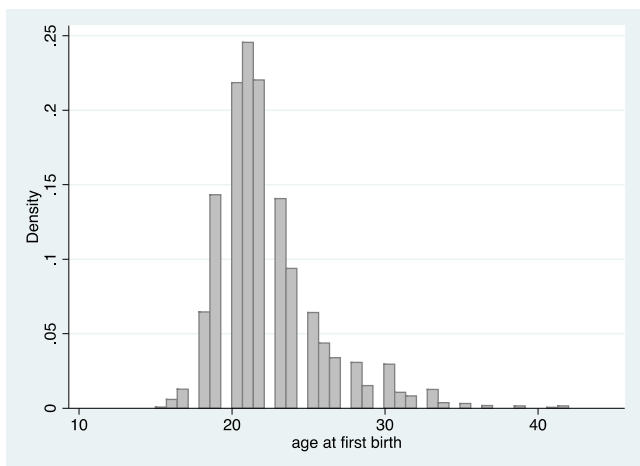

low educated

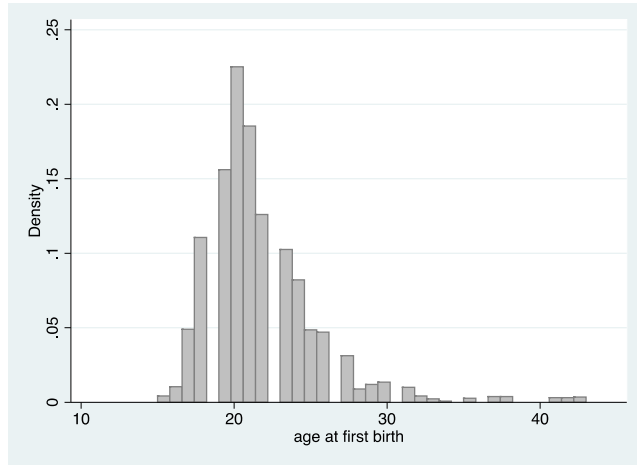

women with higher education

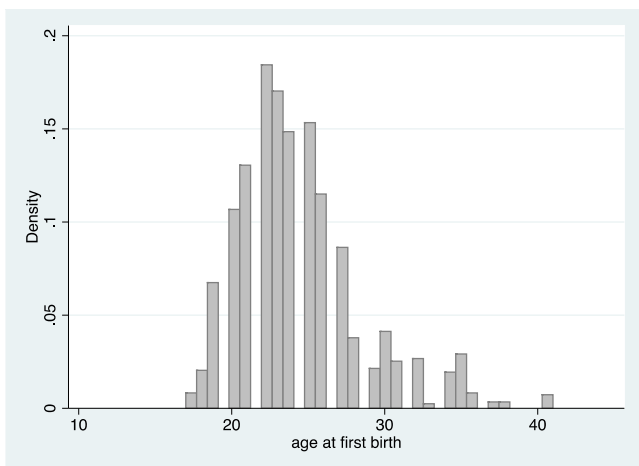

Figure A1. Distribution of age at first birth by education 